\title{
Rapid emergency assessment of ash and gas hazard for future eruptions at Santorini Volcano, Greece
}

\author{
S F Jenkins ${ }^{1 *}$, S Barsotti ${ }^{2,3}$, T K Hincks ${ }^{1}$, A Neri ${ }^{2}$, J C Phillips ${ }^{1}$, R S J Sparks ${ }^{1}$, T Sheldrake ${ }^{1}$ and G Vougioukalakis ${ }^{4}$
}

\begin{abstract}
Hazard assessments for long-dormant volcanoes, where information is rarely available, typically have to be made rapidly and in the face of considerable uncertainty and often poor information. A conditional (assuming an eruption), scenario-based probabilistic approach to such an assessment is presented here for Santorini volcano (Greece). The rapid assessment was developed and implemented in response to the 2011-2012 unrest crisis in order to inform emergency management and planning. This paper synthesises the results presented to the Greek National Committee and scientific community involved. Two plausible eruptions at Santorini were investigated, using multiple inputs and dispersal models, based on observations of historic eruptions and expert judgement. For ash hazard, a 'most likely' eruption scenario was developed, characterised by slow lava extrusion over periods of one to two years with weak but persistent explosions and ash venting up to $3 \mathrm{~km}$. A second 'largest considered' sub-Plinian explosive scenario assumed a $12 \mathrm{~km}$ high column of 4-h duration. For gas hazard, constant fluxes of 200 and 800 tons/day $\mathrm{SO}_{2}$ were assumed for the duration of the eruption scenarios, noting that there is very little evidence to constrain $\mathrm{SO}_{2}$ flux from Santorini eruptions. Statistical models of likely wind conditions with height and season were developed from decadal reanalysis time series showing that consistent low-altitude winds were rarely maintained for more than a few days. Stochastic models of ash (TEPHRA2, VOL-CALPUFF) and gas (AERMOD) dispersal provided outputs in the form of probability maps and exceedance probability curves for key loading and concentration thresholds at important locations on the island. The results from the rapid assessments presented in this paper confirm that ash and gas hazard is likely to be of concern if an eruption of Santorini occurs. Higher hazard may be expected to the south and east of the volcano, notably at important tourist and transport hubs. Low hazard to the north and northwest suggests that these may be suitable locations for emergency response centres and emergency critical infrastructure. This approach may provide a blueprint for rapid ash and gas assessment for other long-dormant volcanoes and we provide suggestions for refining the methods used.
\end{abstract}

Keywords: Volcanic hazard and risk assessment; Ash and gas dispersal modelling; Scenario-based probabilistic hazard modelling; Emergency management planning; Santorini Volcano; Greece

\section{Introduction}

Unrest on long-dormant volcanoes, for which hazard information is commonly sparse, typically requires rapid hazard assessment, given that possible onset of eruption may be within days to months of the start of unrest. Assessments have to be made promptly to inform decisionmaking and planning for an emergency. However, the information that is required as input for such assessments

\footnotetext{
* Correspondence: Susanna.Jenkins@bristol.ac.uk

'Department of Earth Sciences, University of Bristol, Bristol BS8 1RJ, UK Full list of author information is available at the end of the article
}

may be incomplete, of poor quality or even non-existent. It is likely that such volcanoes either have no historic record or that the last historic eruption was prior to the availability of modern instrumental monitoring, which is now common on many active volcanoes (Sparks et al. 2012). Some important types of data, such as volcanic emissions, may thus be completely absent and there will be limited time for gathering new data or carrying out new research. In these cases, information from similar volcanoes with better information may help in estimating some critical parameters. 
Here we describe rapid hazard assessments carried out for Santorini volcano, Greece, during a recent period of unrest (2011-2012). The last eruption of the volcano was in 1950 and was relatively weak, however historical and geological records suggest that larger eruptions were possible. The assessments presented here were carried out to inform the Greek National Committee and assist them in considering emergency management and planning for a future eruption. This approach may provide a blueprint for rapid ash and gas assessment for other long-dormant volcanoes.

\section{Study overview}

Following approximately 60 years of relative quiescence at Santorini volcano, Greece, seismic swarms and expanding radial deformation began in January 2011, continuing throughout the year before dying down early in 2012 . Deformation and seismicity were focussed in the northern portion of the caldera, approximately $4 \mathrm{~km}$ below the surface (Newman et al, 2012; Parks et al, 2012; Parks et al, 2013). Observations of this sequence of unrest were unprecedented at Santorini and raised concerns about the impact of a future volcanic eruption. In response to this, and in collaboration with the Greek National Committee for the Scientific Monitoring of Santorini Volcano, we undertook preliminary studies of the potential ash and gas hazards from an eruption at Santorini. The hazards from emissions of volcanic ash and gas are of particular significance because of their potential impact on the island's population, economy and critical infrastructure. In particular, closure or disruption of roads, the airport or port may limit the scope of any evacuation or other emergency management actions, such as the provision of supplies or clean-up.

This paper describes two parallel rapid hazard assessments that were co-ordinated by two different research groups and undertaken during the state of unrest in late 2011 and early 2012 as concern about volcanic unrest grew. Two of the authors (RSJS and GV) were part of a small group of scientists convened by the local authorities on Santorini to provide advice and expertise to inform the authorities about the potential for eruption and possible impacts. The hazard assessments were carried out rapidly to inform this advice. Results were delivered to the Greek National Committee in May and July 2012 and discussed during scientific meetings on Santorini in March 2012 and October 2012. A further parallel investigation was carried out for the Committee that combined multiple strands of observational and scientific evidence to quantitatively assess the relative probabilities of different unrest outcomes (see Aspinall and Woo, 2014). Our ultimate aim was to link the assessments so that long-term and real-time revised hazard assessments may be carried out as new evidence becomes available, potentially also contextualising volcanic hazards alongside other risks facing the island, such as tectonic earthquake and tsunamis. However, the unrest at Santorini subsided through 2012 and the studies were not progressed to this stage. Ideally, and prior to any future unrest emergencies, such assessments should be elaborated upon and reviewed in detail.

A small number of plausible eruption scenarios at Santorini were investigated based on observations of historic eruptions and expert judgement, and using stochastic models of ash and gas dispersal. Different tools and data sets were employed by the two groups but both hazard assessments used consistent input data of the eruption scenarios. Ash and gas hazard modelling outputs were produced as probability maps for exceeding key critical thresholds and exceedance probability curves for key locations. We have since bought together the studies to compare and contrast dispersal modelling outputs and to make available a more comprehensive initial evaluation of potential ash and gas hazard at Santorini and to suggest emergency management measures. This paper describes a methodology for near real-time hazard assessment at volcanoes showing signs of unrest, and should not be used in place, or as an exemplar of, a comprehensive volcanic hazard and risk assessment. More detailed study, without the time and data constraints that are imposed by an emergency, is advisable for Santorini before a further period of unrest or an eruption.

\section{Volcanic setting}

Santorini is the most active volcano in the South Aegean volcanic arc. It comprises a caldera that formed during the catastrophic Thera eruption approximately 3600 years ago, one of the largest volcanic eruptions recorded in human history. Currently Santorini volcano is within an effusive phase with dacitic volcanism focussed on the Kameni islands (Fig. 1), which rise $500 \mathrm{~m}$ above the flooded caldera floor and represent the peak of a sub-aerial shield volcano constructed on a cone of hyaloclastites and submarine lava. Previous inter-caldera phases have been characterised by extended periods of lava effusion and sporadic tephra emission, leading to the intercalations of lava and tephra layers exposed within the caldera cliffs (Druitt et al, 1999).

Palea Kameni, which formed after the Thera eruption, last erupted in $726 \mathrm{AD}$ after seven centuries without any record of activity. Historical and geological evidence for significant pumice generation and ash plumes several kilometres high suggest this was an explosive sub-Plinian event. Following 726 AD, Santorini was then quiet until more frequent eruptions began in $1570 \mathrm{AD}$ forming the Nea Kameni islands. Nea Kameni has erupted seven times in the past 500 years, each involving extrusion of viscous lava to form domes and thick flows and accompanied by 


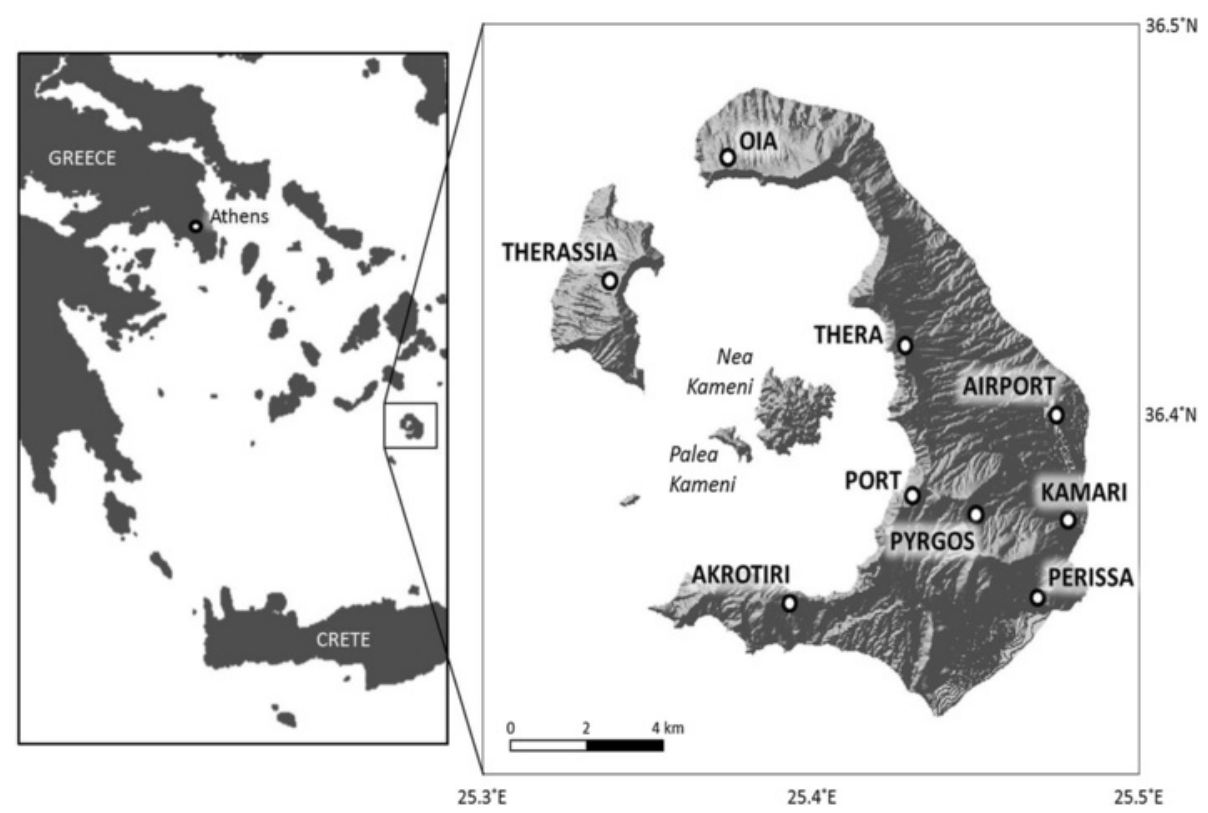

Fig. 1 Map of Santorini caldera, and its location within Greece, the recent volcanic islands of Nea Kameni and Palea Kameni and nine key locations considered in our assessment of the potential ash and gas impacts from a future eruption at Santorini volcano

intermittent ash explosions over a few months or years (Smithsonian Institution 2013).

There is limited historical information on unrest activity at the volcano. What is available suggests that eruptions are preceded by an extended period (weeks to months) of felt seismicity and local deformation immediately (days) prior to eruption (Fytikas et al, 1990; Pyle and Elliot, 2006). There are also records of unrest prior to the 2011-2012 unrest episode that did not result in eruption (e.g. Stiros et al, 2010).

\section{Economic and demographic setting}

Santorini island is home to just over 15,000 people (Hellenic Statistical Authority 2011), which can swell to more than 500,000 in the summer months. The well-established tourism industry on the island has led to significant economic and population growth and the majority of the permanent population are employed within the tourist sector. Only a small proportion of the population still have traditional occupations of fishing and viniculture (DomineyHowes and Minos-Minopoulos, 2004; Vougioukalakis and Fytikas, 2005). Thus all livelihoods are at risk from a future volcanic eruption and any evacuation, unrest or nonmagmatic activity (e.g. phreatic eruptions) is capable of having a significant impact upon the local economy.

\section{Stochastic hazard models}

In carrying out the parallel rapid hazard assessments described in this paper, two ash models were used: TEPHRA2 (Bonadonna et al, 2005) to allow for rapid computation of ash fall hazard and VOL-CALPUFF (Barsotti et al, 2008) to assess the airborne ash hazard. VOL-CALPUFF also outputs the ash fall hazard and so we were able to quantitatively compare the hazard outputs from numerically different approaches to ash fall modelling. The rationale for assessing the hazard independently using different models and datasets is not to carry out a systemic model comparison but to describe how science is undertaken by different groups in an emergency: broadly similar hazard outputs would strengthen our confidence in the presented results. For modelling of gas $\left(\mathrm{SO}_{2}\right)$ dispersal, the boundary layer pollution model AERMOD (Cimorelli et al, 2005) was used. In what follows, we briefly introduce each of these models before discussing the statistical models of wind conditions developed for the study.

\section{TEPHRA2}

TEPHRA2 is a Eulerian dispersal model that assumes an initial released mass of ash distributed between the ground and the plume top for a single event (Bonadonna et al, 2005). Particles are then advected by a steady-state wind at source and spread out by atmospheric diffusion, diluting their concentration. Particles fall according to terminal velocities that account for Reynold's number variations along the particle's fall to earth, derived from the particle size distribution and the stratified wind field (Bonadonna et al, 2005). Model inputs are shown in Table 1 and were estimated from expert judgement, based on experience and knowledge of the scientific literature and analogous volcanoes. As we were concerned with 
Table 1 Ash modelling inputs for an expected most likely future eruption at Santorini

\begin{tabular}{|c|c|c|}
\hline Model input parameter & Value & Description \\
\hline Vent elevation & 367 & (m) From Smithsonian Institution (2013) \\
\hline Eddy constant & 0.04 & $\begin{array}{l}\text { Eddy diffusion value for Earth for small } \\
\text { particles (Suzuki, 1983) }\end{array}$ \\
\hline Diffusion coefficient & 142.6 & $\begin{array}{l}\text { Describing the advection and diffusion } \\
\text { of large particles }\left(\mathrm{m}^{2} / \mathrm{s}\right)\end{array}$ \\
\hline Fall time threshold & 188.6 & $\begin{array}{l}\text { Threshold for change in diffusion } \\
\text { calculation (seconds fall time) }\end{array}$ \\
\hline Particle density & 2300 & Assumed density of particles $\left(\mathrm{kg} / \mathrm{m}^{3}\right)$ \\
\hline Plume steps & 200 & Number of column integration steps \\
\hline Particle classes & 100 & Number of particle size classes \\
\hline Plume ash distribution & 0 & $\begin{array}{l}\text { Initial mass uniformly distributed from } \\
\text { base to top of plume }\end{array}$ \\
\hline
\end{tabular}

proximal on island deposits ( $<10 \mathrm{~km}$ from source), the diffusion coefficient and fall time threshold were relatively low to be appropriate for the area scale of the modelling (Bonadonna et al, 2005). Model outputs for each simulation comprise the ash load at each cell, with target cells computed individually rather than across a uniform 'grid', giving an ash load 'footprint' for each released ash mass.

\section{VOL-CALPUFF}

VOL-CALPUFF couples a Eulerian description of plume rise with a Lagrangian representation of ash dispersal as a series of diffusing packets (Barsotti et al, 2008). The model is able to describe the tilting effects of the plume due to wind action and uses orography-corrected meteorological and volcanological conditions that simulate the transient and three-dimensional transport of volcanic ash throughout the eruption duration. The settling velocities of particles are described as a function of particle characteristics (density, size and shape) and atmospheric conditions. VOL-CALPUFF is therefore a useful tool for reconstructing and forecasting both ash concentrations in the air and ash fallout (dry and wet) on the ground from the same scenario (Barsotti and Neri 2008; Spinetti et al, 2013). To enable comparison of the ash fall footprints from VOL-CALPUFF with those derived from TEPHRA2 we deliberately used the same volcanological input parameters for the two models (Table 1). For the presented results, VOL-CALPUFF has been run by using hourly meteorological data pre-processed by using CALMET (Scire et al. 1990).

\section{AERMOD}

AERMOD is a widely used boundary layer pollution model that involves release of a source plume of tracers (e.g. $\mathrm{SO}_{2}$ or ash), which are then tracked as they are carried by wind and interact with topography (Cimorelli et al, 2005). The model has been applied at Masaya volcano in Nicaragua and compared well with measurements of $\mathrm{SO}_{2}$ concentration (Johns, 2010). Input parameters include vent radius, vent velocity, exit temperature and tracer flux (Table 2). These parameters are not independent because values have to be internally consistent since tracer flux depends on radius and velocity. Near ground concentrations of $\mathrm{SO}_{2}$ are calculated and reported here. Results are weakly sensitive to variations of velocity and radius for fixed mass flux because overall source buoyancy is constant and plume heights are only weakly dependent on initial momentum.

\section{Wind conditions}

The wind is a primary control on dispersal of ash and gas. Statistical analysis of wind data at different altitudes characterises variability of wind speed and direction as functions of height. Model wind data were sourced for TEPHRA2 from the European Centre for Medium Range Weather Forecasts (www.ecmwf.int) and constitute 20 years of daily averaged regional ERA-Interim re-analysis data (1990 to 2011) sourced from a $0.7^{\circ}$ grid. Model wind data for use with VOL-CALPUFF were sourced from the National Centers for Environmental Prediction and Atmospheric Research (www.cpc.ncep.noaa.gov) and constitute 10 years of regional re-analysis data (1980 to 1990) available on a $0.75^{\circ}$ grid with a temporal resolution of $6 \mathrm{~h}$. The different types of wind data adopted by the two models were a result of the different nature of the two dispersal models and also the requirement for wind data to be pre-processed and rapidly available so that model outputs

Table 2 Gas modelling inputs for an expected most likely future eruption (a 200 tons/day or 800 tons/day scenario) at Santorini

\begin{tabular}{|c|c|c|}
\hline $\begin{array}{l}\text { Model input } \\
\text { parameter }\end{array}$ & Value & Description \\
\hline Vent elevation & $113 \mathrm{~m}$ & From Pyle and Elliot, 2006 \\
\hline Exit temperature & $1000 \mathrm{~K}$ & $\begin{array}{l}\text { Typical temperature of magmatic } \\
\text { gases from dacitic magma }\end{array}$ \\
\hline Proportion of $\mathrm{SO}_{2}$ & $5 \%$ & $\begin{array}{l}\text { As a proportion of erupted gas, } \\
\text { the other gas being water }\end{array}$ \\
\hline Gas exit velocity & $10 \mathrm{~m} / \mathrm{s}$ & Estimate made from typical values \\
\hline Gas exit density & $0.12 \mathrm{~kg} / \mathrm{m}^{3}$ & Density of water at $1000 \mathrm{~K}$ \\
\hline Vent diameter & 7 or $14 \mathrm{~m}$ & $\begin{array}{l}\text { Given gas density and concentration, } \\
\text { a } 7 \text { m diameter vent is required to } \\
\text { emit } 200 \text { tons/day. To conserve mass, } \\
\text { keeping temperature and velocity } \\
\text { constant, an } 800 \text { tons/day emission } \\
\text { requires a } 14 \mathrm{~m} \text { diameter }\end{array}$ \\
\hline Albedo & 0.25 & $\begin{array}{l}\text { Fraction of total incident solar } \\
\text { radiation reflected by the surface } \\
\text { (typical value for grassland used) }\end{array}$ \\
\hline Bowen ratio & 5 & $\begin{array}{l}\text { Net radiation at a surface (typical } \\
\text { value for grassland used) }\end{array}$ \\
\hline Surface roughness & $0.15 \mathrm{~m}$ & Typical value for grassland used \\
\hline
\end{tabular}


could be obtained as quickly as possible. As an advectiondiffusion model, TEPHRA2 uses a single time-averaged wind record at source that does not vary with time; by contrast, VOL-CALPUFF accounts for temporal and spatial variation in the wind and therefore requires processing of the reanalysis data to provide time-varying and highresolution wind inputs. Figure 2 summarises the data from both data sets with rose diagrams showing the proportions and ranges of wind speed and direction at three different heights and suggests that minimal differences exist in wind statistics between the two datasets. Comparison between the outcomes from the two models and their underlying wind datasets (Comparison of model outputs) allowed us to evaluate the effect of different models and model input data on hazard analyses and therefore to highlight the most robust outcomes of the assessment.

The key features of the wind statistics are the predominance of northerly winds at low altitude $(<1 \mathrm{~km})$ while there is a dominance of westerly and north-westerly winds at higher altitudes, which are weaker over the summer months (June to August). Wind speeds are mostly below 10 to $20 \mathrm{~m} / \mathrm{s}$ at lower altitudes $(\leq 3 \mathrm{~km})$ but at higher altitudes relevant to the sub-Plinian scenario $(12 \mathrm{~km})$, speeds are commonly up to 30 to $40 \mathrm{~m} / \mathrm{s}$. These wind characteristics have first order hazard implications discussed later. Another useful parameter when considering ash dispersal is wind persistence towards a given direction. We divided direction into eight $60^{\circ}$ sectors and used the two sets of re-analysis data to calculate separately the statistical distribution of the number of days that the wind persisted in that direction. Salient examples are shown in Fig. 3 and they indicate that the ECMWF and NCEP/NCAR datasets produce similar information on wind conditions at Santorini. Analysis of these data shows that a consistent low altitude wind direction is rarely maintained for more than a few days. Thus it is highly probable that in a prolonged eruption all parts of the island will be affected.

\section{Scenario identification}

Given the rapidity of this study, being carried out during the unrest crisis, and the limited supporting data available to characterise a full suite of eruption scenarios with appropriate distributions and parameterisation, we chose to consider only a small number of plausible and representative scenarios. Using arbitrary choices based on such few data (even with input from expert judgement) to inform a fully probabilistic assessment may have suggested that model parameters (and associated uncertainties) were well constrained, leading to a false degree of confidence in the output. Conversely, had input ranges been used that represented the (true) high degree of uncertainty, rather than those refined through the use of scenarios, resulting outputs would vary so much as to have little practical value. The outputs provde a starting point from which to identify potential hazards and areas at greatest risk so as to inform further, more detailed, analysis. Ideally, hazard assessment

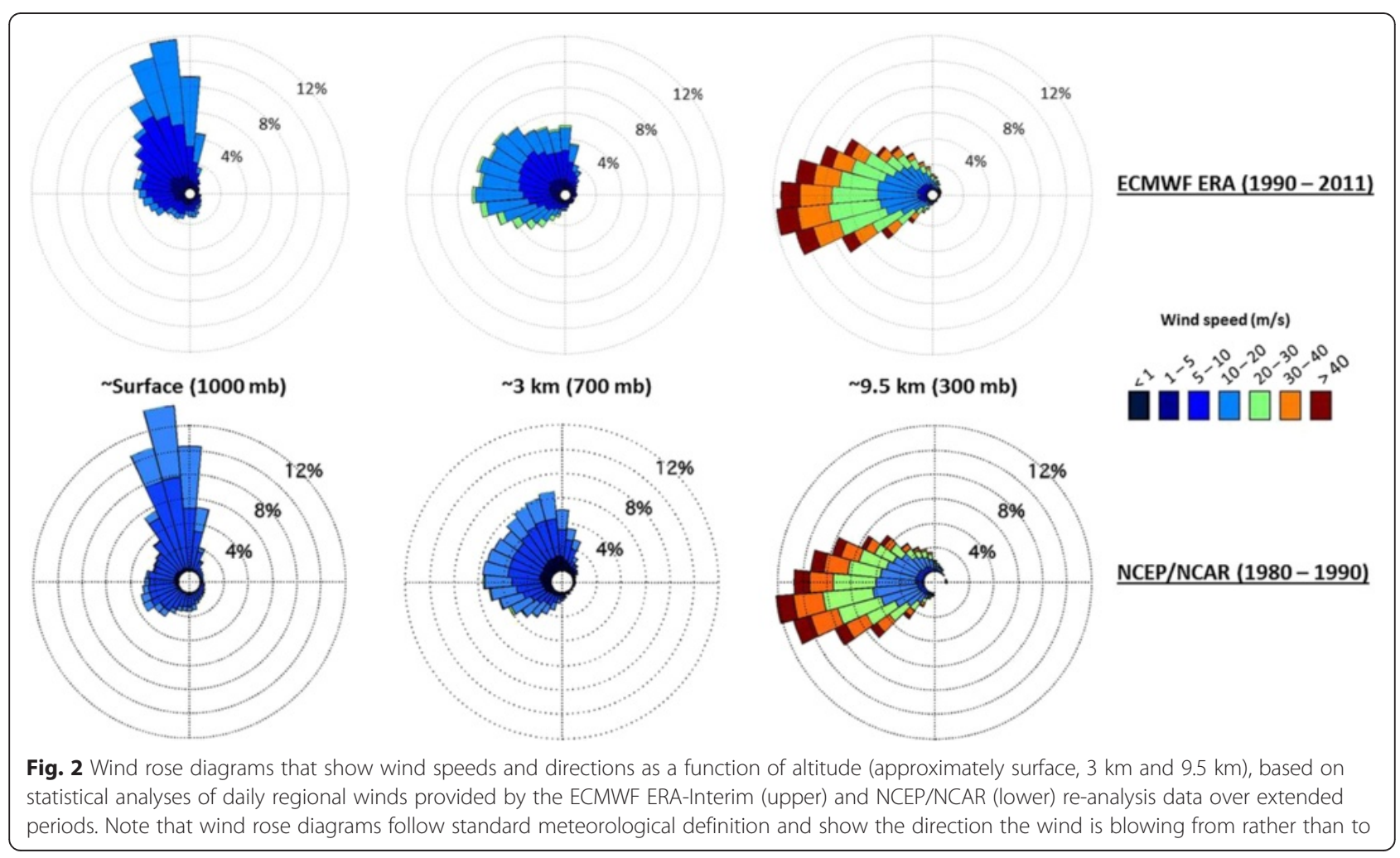



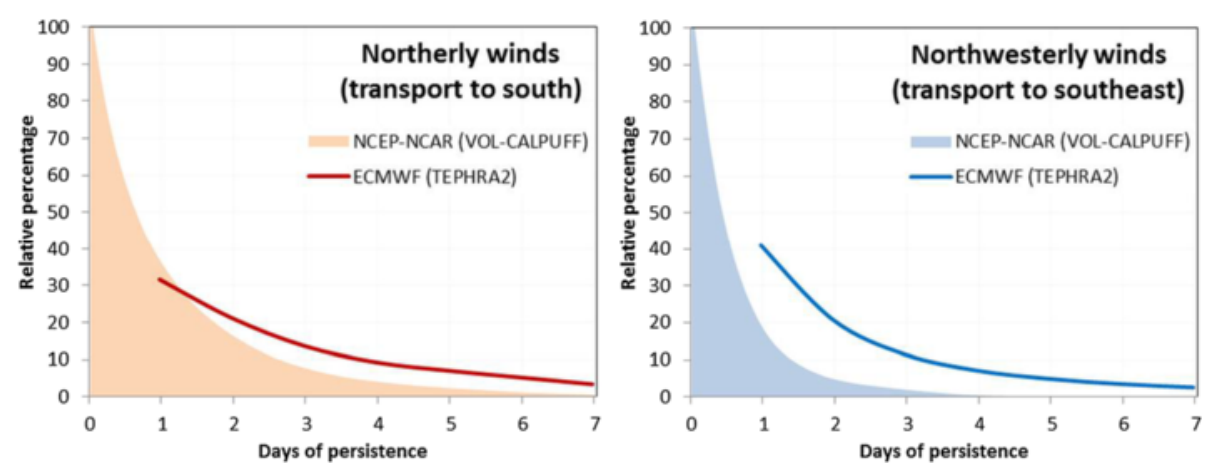

Fig. 3 The directional persistence of low altitude winds exhibited by the datasets used in modelling: ECMWF ERA-Interim (used by TEPHRA2) and NCEP-NCAR (used by VOL-CALPUFF), for two representative $60^{\circ}$ sectors: towards the south and towards the southeast

at long dormant volcanoes would draw in more analogue and volcano-specific data and carry out more detailed time-series analysis than was possible at the time of the Santorini crisis. We would also recommend that a range of experts be elicited, formally or informally, in order to quantify better the credible ranges over which scenarios and inputs vary. Where possible, identifying which outputs are of most importance for emergency managers would help in deciding which inputs to focus on.

The eruption history at Santorini exhibits three main styles of eruption: 1) caldera-forming eruptions with a Volcanic Explosivity Index (VEI) of 6 or 7, analogous to the 3600 Ka Thera eruption; 2) sub-Plinian explosive (VEI 4) eruptions, similar to that of $726 \mathrm{AD}$; and 3) longduration weak ash emissions that accompany extrusion of lava, as seen at Santorini over the last 500 years (Fytikas et al. 1990; Druitt et al, 1999; Pyle and Elliot, 2006; Smithsonian Institution 2013). An eruption similar to the Thera eruption would blanket the island of Santorini in pyroclastic deposits and have significant regional, and global, effects. However, the recurrence interval of such an eruption is approximately 15 to 20 thousand years (Dominey-Howes and Minos-Minopoulos, 2004) and the consensus interpretation is that Santorini is in a postcaldera shield-building stage of volcanism. Thus we considered this eruption style very unlikely in the current impact assessment. We therefore restricted our assessment to two scenarios: a 'most likely' weak ash plume based on recent historical eruptions of 1866-70, 1925-26 and 1939-40, and a 'largest considered' sub-Plinian event, based on evidence of significant pumice generation in the eruption of $726 \mathrm{AD}$ and on geological records that suggest Santorini is capable of powerful mid-intensity explosive eruptions. As a consequence, for each scenario, we only account for aleatoric uncertainty in the wind conditions at the time of eruption by simulating a large number of runs into multiple wind conditions producing conditional (assuming an eruption) probabilistic outputs. The volcanological inputs for modelling of these scenarios are detailed over the next sections.

\section{Most likely scenario}

The perceived 'most likely' future eruption scenario at Santorini is informed by the studies of Fytikas et al. (1990), Pyle and Elliot (2006) and Watt et al. (2007) and by descriptions of past eruptions, notably 1866-70, 192526 and 1939-40. Historical observations at Santorini indicate that ash emissions are related to intermittent explosions and ash venting that occurs contemporaneously with extrusion of lava. Compared to many other arc volcanoes, explosive activity is quite small in magnitude and weak in intensity. The largest events consist of Vulcanian explosions that can eject blocks of rock as far as $2 \mathrm{~km}$ from the vent and produce ash plumes that reach up to $3 \mathrm{~km}$ height. However, most of the explosive activity is less intense, generating plumes in the range of a few hundred metres to not much more than $1 \mathrm{~km}$ height. Hazards associated with these eruptions include the ejection of ballistics during explosions, the dispersal and fallout of ash and the release of volcanic gas from the vent and as lava enters the sea (Fytikas et al, 1990). Historical accounts suggest that the range of ballistics is about $1 \mathrm{~km}$ (Fytikas et al, 1990). As there are no settlements within $2 \mathrm{~km}$ of the likely future vent on the Kameni islands we did not further consider the potential impact from ballistics, although large ships that necessarily pass close to the likely future vent on Nea Kameni islands en route to the Port may be at risk from this hazard.

\section{Ash modelling inputs}

For modelling ash production from the most likely scenario (using TEPHRA2 and VOL-CALPUFF), we assumed a two-year eruption duration and constrained inputs using the detailed observations of plume heights during eruptions in 1925-28 (Reck, 1936), 1939-40 (Georgalas and Papastamatiou, 1953) and detailed descriptions of the 
1866-70 eruption by Schmid (1874), Fouqué (1879) and Dekigalla (1881), and also considering some of the eruption data summarised by Watt et al. (2007). During any of the previous eruptions, a maximum plume height of around $3200 \mathrm{~m}$ was observed (in 1925), with minimum plume heights in the order of a few tens to hundreds of metres. We therefore chose to model four separate plume heights: $0.5,1,2$ and $3 \mathrm{~km}$, on the basis that this accounted for the variability observed in previous eruptions and therefore covered what was likely for a future most likely scenario. By modelling specific plume heights, rather than a continous range between 0.5 and $3 \mathrm{~km}$, we could then provide individual hazard maps for different plume heights. We consider that this approach was appropriate for emergency managers in permitting near real-time forecasting of the hazard from specific events and for scenario planning. Two separate cases for ash production during a most likely scenario eruption are described here to account for different approaches to calculating mass flux from plume height. The vast majority of Vulcanian plumes are best characterised as starting plumes. Volcanic ash plumes are only modelled as thermals if the event is very close to being instantaneous; by contrast, the source explosion supplying a starting plume does so over times comparable to, or greater than, the time taken for the plume to rise to its neutral buoyancy height (see Sparks and Wilson, 1982; Sparks et al, 1997). Observations of the ash plume spreading rate can be used to distinguish easily between a thermal and a sustained or starting plume as the entrainment coefficient is about 0.25 for a thermal and about 0.1 for a sustained or starting plume (Sparks et al, 1997). This leads to a height to width ratio of approximately 25 and 10 respectively. The majority of plumes generated by Vulcanian explosions, including historic photographs of Santorini explosions, are closer to 10 than 25 , indicating that they are best characterised as starting plumes.

There are well established empirical relationships between plume height and mass flux (e.g. Sparks et al, 1997; Mastin et al, 2009) based mostly on powerful eruptions, and these are widely used to assess ash hazard to aviation. Santorini 'Strong' assumes that this relationship is valid. However, recent studies suggest that these relationship are not accurate for weak plumes strongly affected by wind, e.g. 2010 Eyjafjallajökull eruption, Iceland. The Santorini 'Weak' scenario accounts for this using the scaling relationship of Woodhouse et al. (2013) with the scenario column heights and wind shear calculated from averaged reanalysis data, which results in an order of magnitude increase in mass flux (Table 3). The total time and the total mass fraction of erupted ash has been calculated for the baseline Santorini Strong and Weak scenarios (Table 4), given the calculated mass fluxes and an estimate of total erupted volume from historical eruptions at Santorini. Only a very small percentage of magma erupted in a most likely scenario is expected to be ash $(0.1 \%$ in Santorini Strong and $1 \%$ in Santorini Weak). Over the assumed two-year period the percentage of time the models assume ash is generated is $15.3 \%$ and $7.6 \%$ of the total time, respectively. These numbers are indicative and qualititatively consistent with descriptions of historic eruptions. The 'Santorini Weak' case, where we considered the effect of local wind conditions on bending over a weak plume, gives higher mass loadings than assuming no wind-plume interaction ('Santorini Strong') because of the increased mass. Thus the calculated hazard will be higher during ashing events in this case, although there are more periods when there is no ash.

To speed up simulation time, a synthetic catalogue of ash footprints was produced by modelling individual ash plumes of fixed mass and height $(0.5,1,2$ and $3 \mathrm{~km}$ : Table 3) into each daily wind record from more than 10 years of re-analysis wind data (see Wind conditions). This approach allows for the influence of varying wind conditions in forecasting the potential ash hazard footprint from any one eruption. Sampling from the ranges identified in Table 3, we simulated up to 10,000 events with the eruption start randomly sampled from within the synthetic catalogue. In the absence of sufficient historic data to develop a full statistical model, a time series for each eruption was determined by modelling interevent times for each plume size bin $(0.5,1,2$, and $3 \mathrm{~km})$ as independent Poisson processes, each with a different rate parameter based on historical observations (see Table 3). Modelled event durations and eruption frequencies resulted in similar total erupted masses in each event bin. Alternate inter-event distributions could not be justified because of the lack of available data; what data are available suggest that statistical repose models vary between eruption cycles (Watt et al, 2007). Given more time, detailed time-series analyses of previous eruptions could be used to justify additional scenario variants that employ alternative distributions for inter-event times. For instance, a magnitude-frequency relationship based on past eruption time-series could have been used to simulate the inter-event duration and subsequent explosion magnitude using a marked point process. If there were sufficient data to fit such a model, this approach would account for mass/height variation and enable simulation of event clustering. How useful this would be relative to further refining alternate input data would depend upon the perceived value of the different outputs: for example, inter-event times inform cumulative estimates and durations of ash hazard over the total eruption but do not affect individual plume height hazard maps. Historically, eruptions at Santorini typically last a few years, with explosive activity intermittent throughout but more prominent in the early months of the eruption. Scenario variants such as clustering could only be very loosely characterised 
Table 3 Volcanological inputs for a 'most likely' long-duration ash emission with assumed event mass and duration (and thus mass flux) given two scenario cases: 'Strong' assumes that the Sparks et al. (1997) empirical relationship between plume height and mass flux is valid (i.e. the plume is not strongly affected by wind), while 'Weak' considers that the plume is affected by wind and follows the relationship of Woodhouse et al. (2013)

\begin{tabular}{|c|c|c|c|c|c|c|c|}
\hline \multirow{2}{*}{$\begin{array}{l}\text { Height } \\
(\mathrm{km})\end{array}$} & \multirow{2}{*}{$\begin{array}{l}\text { Number of } \\
\text { events }\end{array}$} & \multirow{2}{*}{$\begin{array}{l}\text { Poisson rate } \\
\text { parameter }\end{array}$} & \multicolumn{2}{|c|}{ Event ash mass $\left(\times 10^{6} \mathrm{~kg}\right)$} & \multicolumn{2}{|c|}{ Duration (mins) } & \multirow[t]{2}{*}{ Particle size (phi) } \\
\hline & & & Strong & Weak & Strong & Weak & \\
\hline \multicolumn{8}{|c|}{ Total eruption duration: 2 years } \\
\hline 3 & 5 & 0.007 & 6 & 60 & 10 & 10 & Range: -3.32 to 6.64 \\
\hline 2 & 20 & $2.74 \times 10^{-2}$ & 1.8 & 30 & 15 & 15 & Median: 1.66 \\
\hline 1 & 75 & 0.103 & 1.1 & 5.4 & 120 & 60 & Standard deviation: 2 \\
\hline 0.5 & 400 & 0.548 & 0.2 & 1.1 & 360 & 180 & \\
\hline
\end{tabular}

Scenario variants to investigate the effect of ash aggregation

Particle size is modified to favour larger particles.

Range: -3.32 to 3.32

All parameters as for the base Santorini 'Weak' and 'Strong' scenarios.

Median: 0.00

Standard deviation: 2

Scenario variants to investigate the effect of event clustering

Total eruption duration: 1 year

$\begin{array}{llll}3 & 5 & 0.014 & \text { Increased Poisson rate parameter simulates shorter inter-event times. } \\ 2 & 20 & 5.48 \times 10^{-2} & \\ 1 & 75 & 0.205 & \text { All other parameters as for the base Santorini 'Weak' and 'Strong' scenarios. } \\ 0.5 & 400 & 1.096 & \end{array}$

Duration refers to individual events, rather than the total eruption duration, and relates to the event ash mass and calculated mass flux. Further variants build upon these base scenarios to investigate the influence of aggregation and event clustering on simulated hazard

due to lack of data. To begin to investigate the effect of event clustering on the potential ash hazard, a modification to the base Santorini Strong and Weak scenarios is identified where we simulate a non-stationary Poisson process by increasing the Poisson rate parameter to account for shorter inter-event times, and therefore clustering of events (with the total duration of the ash-producing portion of eruption assumed to be 1 year, see scenario variations in Table 3).

Grain size distributions (Table 3) are based on qualitative descriptions of 'sandy to very fine' ash in Santorini eruptions (Kténas, 1926). However, a common process in volcanic eruptions is particle aggregation, in which fine ash (typically $<64 \mu \mathrm{m}$ ) is deposited in the form of

Table 4 Summary values for the two 'most likely' scenario cases at Santorini. The 'Strong' case assumes no influence of the wind upon the plume (Sparks et al, 1997) and the 'Weak' considers that the plume may be affected by wind (Woodhouse et al, 2013)

\begin{tabular}{lll}
\hline Scenario case: & Strong & Weak \\
\hline Total mass of ash: & $2.33 \times 10^{8} \mathrm{~kg}$ & $1.73 \times 10^{9} \mathrm{~kg}$ \\
Total mass of lava: & $2 \times 10^{11} \mathrm{~kg}$ & $2 \times 10^{11} \mathrm{~kg}$ \\
Ratio of ash to lava: & $\sim 1: 1000$ & $\sim 1: 100$ \\
Eruption duration: & 2 years & 2 years \\
Duration of ash emission: & $15.3 \%$ of time & $7.6 \%$ of time \\
\hline
\end{tabular}

clusters containing tens of thousands of particles. These aggregated particles deposit much more quickly than the individual particles, but often break up on impact with the ground. The resulting increased abundance of very fine ash exacerbates health hazards (Horwell and Baxter, 2006). Commonly the mass fraction of fine ash can exceed $50 \%$, but this is not known from Santorini eruptions. To simulate the effect of particle aggregation on ash dispersal and deposit loading on the ground, we investigate a further variant of both the 'Santorini Strong' and 'Weak' scenarios. Aggregated particles are assumed to be in the reduced range $1 \mathrm{~cm}-100$ microns (phi -3.32 to 3.32), but with a modified grain size distribution that favours larger particle sizes (Table 3 ). This modification is purely qualitative and requires further investigation and grain size characterisation before being used in a more comprehensive assessment.

For these six scenario variants (Table 3), individual event deposits and cumulative mass loads (total deposit from all events over the 1 or 2 year duration of the eruption) were logged for each grid location and used to produce probability of exceedance curves. The deposits (from all plumes) for each day of the eruption were also summed to get the cumulative daily, weekly, monthly and total deposit at any given site. Results for the six variants were presented separately to elucidate the effect of different mechanisms on the hazard and also to allow 
direct comparison between the models. Exceedance probability maps and curves were also produced for each of the fixed height plumes to show the likely hazard associated with any one event.

\section{Gas modelling inputs}

Significant health effects from magmatic gases have been historically documented during past eruptions of Santorini (Dakoronias, 1879). However, no direct measurements of $\mathrm{SO}_{2}$ fluxes exist for these events making it difficult to constrain likely fluxes in a future eruption. For the emergency assessment, we considered two daily averaged fluxes for the most likely two-year scenario: 200 tons/day and 800 tons/ day. Fluxes have been estimated based on petrological analyses and inferred discharge rates for previous eruptions. Using a typical sulphur content of $1000 \mathrm{ppm}$ for dacitic magmas and magma discharge rates of $1 \mathrm{~m}^{3} / \mathrm{s}$, similar to those observed historically (Pyle and Elliot, 2006), a default scenario with a constant flux of 200 tons per day is provided. Such a value is characteristic of many effusive eruptions of dacitic arc volcanoes, such as Mount Unzen, Japan, 1991-1995 (Hirabayashi et al, 1995) and Mount Saint Helens, USA, 2004-2005 (Gerlach et al, 2008). Higher fluxes of $\mathrm{SO}_{2}$ may be expected if there is an increased erupted mass flux (i.e. Santorini Weak) or more explosive activity. Furthermore, many arc volcanoes exhibit an "excess degassing" phenomena where fluxes of $\mathrm{SO}_{2}$ are too large to originate exclusively from the magma that is erupted, suggesting that other $\mathrm{SO}_{2}$ sources are contributing (Shinohara, 2008). A scenario based solely on mass fluxes (as for the 200 tons/day case) could therefore be an underestimation of the true flux; however, reliable constraints for sources and fluxes of $\mathrm{SO}_{2}$ could not be achieved. A best estimate of 800 tons/day was chosen, which reflects the elevated fluxes expected from an eruption with increased mass flux or excess degassing. This value was based on expert judgement and gas fluxes from analogous arc volcanoes that exhibit more explosive activity and degassing over similar two-year timescales, such as Mount Augustine (McGee et al, 2010).

We chose values of gas exit velocity, vent radius and gas exit density that were consistent with the mass flux identified (200 or 800 tons/day) and an $\mathrm{SO}_{2}$ proportion of $5 \%$, using the standard equation for state of water at $1000 \mathrm{~K}$ at 1 atmosphere to calculate the gas exit density. For each eruption scenario, 100 two-year simulations were randomly sampled from a synthetic catalogue of 379 simulations to obtain $0.05,0.5$ and 0.95 probability of exceedance values. Initial wind conditions were sampled from within a 20-year record and daily wind records over the following two years were used.

\section{Largest considered scenario}

The second key scenario employed in this study was a sub-Plinian eruption, a largest considered scenario for a future eruption at Santorini, with lower probability of occurrence than the most likely scenarios but higher probability than a large caldera-forming eruption. Based on very limited and uncertain data (one pumice eruption in $726 \mathrm{AD}$ of unknown magnitude out of eight historic eruptions) the chances of the next eruption at Santorini being sub-Plinian are thought to be no more than 1 in 10 and likely much lower given that the past seven eruptions have been largely lava eruptions. For gas outputs, averaged daily values of 800 tons/day may provide a first-order indication of hazard appropriate to a large explosive eruption followed by sustained degassing.

\section{Ash modelling inputs}

Based on analogous sub-Plinian eruptions (Pyle 2000) and the limited historical accounts of $726 \mathrm{AD}$ (Friedrich et al, 2006), we considered a plume height of $12 \mathrm{~km}$ (Table 5) and discharge rate of $1000 \mathrm{~m}^{3} / \mathrm{s}$, which correlates with an erupted mass of $3.3 \times 10^{10} \mathrm{~kg}$ over four hours, given a density of erupted material of $2300 \mathrm{~kg} / \mathrm{m}^{3}$ (following the empirical relationship of Sparks et al, 1997). Ash produced during the largest-considered scenario represents approximately $15 \%$ of the total expected volume, but $150 \%$ of the expected total ash mass in the more voluminous most likely scenario (Santorini Weak). In the absence of specific information, we used the same grain size distribution as for the weak plume scenarios, approximately representing sandy to very fine ash (Table 5). Grain size estimates could be refined using information from analogue sub-Plinian eruptions at other volcanoes. For the sub-Plinian scenario suggested here, it is possible that as much as $40 \%$ of the erupted material would comprise fine ash $(<63 \mu$ or $>4$ phi) (Mastin et al, 2009). This would have the effect of reducing the deposit in more proximal on-island areas as the fine ash fraction would remain in suspension for longer and be carried farther from the vent. Particle density (Table 1) was kept fixed at $2300 \mathrm{~kg} / \mathrm{m}^{3}$; any pumiceous particles will likely be lower density than this and ideally the sub-Plinian scenario would account for this, particularly for more proximal hazard estimation. As with a finer ash mass fraction, reduced particle densities would act to reduce the amount of ash falling out in more proximal areas. However, the uncertainty related to grain size and density characteristics are modest compared to uncertainties related to the relationships between plume

Table 5 Volcanological inputs for a 'largest considered' subPlinian eruption scenario

\begin{tabular}{llllll}
\hline $\begin{array}{l}\text { Plume } \\
\text { height }(\mathrm{km})\end{array}$ & $\begin{array}{l}\text { Number } \\
\text { of events }\end{array}$ & $\begin{array}{l}\text { Mass flux } \\
(\mathrm{kg} / \mathrm{s})\end{array}$ & $\begin{array}{l}\text { Duration } \\
\text { 12 }\end{array}$ & $\begin{array}{l}\text { Mass from } \\
\text { event }(\mathrm{kg})\end{array}$ & $\begin{array}{l}\text { Particle } \\
\text { size }(\mathrm{phi})\end{array}$ \\
\hline 1 & $2.3 \times 10^{6}$ & $4 \mathrm{~h}$ & $3.3 \times 10^{10}$ & $\begin{array}{l}\text { Range: }-3.32 \\
\text { to 6.64 }\end{array}$ \\
& & & & Median: 1.66 \\
& & & & $\begin{array}{l}\text { Standard } \\
\text { deviation: 2 }\end{array}$ \\
& & & &
\end{tabular}


height and mass flux in the source term, duration and the abstraction of historic eruption data as discrete and simplified events. It is unlikely that improving the sophistication in modelling grain size characteristics would affect the firstorder hazard effects and their implication for emergency planning. One simulated event was modelled for each daily wind record, i.e. 7305 simulations in total, to account for uncertainty in likely wind conditions.

\section{Thresholds and critical locations}

Ash fall load thresholds were chosen that approximately related to key hazardous impacts. A threshold of $100 \mathrm{~kg} / \mathrm{m}^{2}$ was identified as a conservative loading above which roof collapse may become an issue for very weak roof types (Blong, 1984), and is approximately equivalent to $10 \mathrm{~cm}$ of dry ash thickness assuming a fall density of $1000 \mathrm{~kg} / \mathrm{m}^{3}$. Using the same ash density assumption, a load of 1 to $10 \mathrm{~kg} / \mathrm{m}^{2}$ is equivalent to between $1 \mathrm{~mm}$ and $1 \mathrm{~cm}$ of ash deposit, and is known to disrupt airport operations, transport, cause damage to crops and in certain cases cause electrical circuits and electronic systems to malfunction (Barsotti et al, 2010; Jenkins et al, 2014; Wilson et al, 2012).

For suspended ash concentrations, we considered the probability of exceeding ash concentrations of $50 \mu \mathrm{g} / \mathrm{m}^{3}$ following the World Health Organisation (WHO) air quality standard for 10 micron particulate matter (PM10), and also $2 \mathrm{mg} / \mathrm{m}^{3}$ and $0.2 \mathrm{mg} / \mathrm{m}^{3}$ as the defined enhanced procedure zone and 2010 safe flying limit for commercial aviation, respectively (ICAO, 2010; Zehner, 2010).

The WHO also provides an Air Quality Guideline (AQG) for daily $\mathrm{SO}_{2}$ concentration thresholds of $20 \mu \mathrm{g} / \mathrm{m}^{3}$, below which air quality is deemed good. The European Commission (EC) provide a daily threshold of $125 \mu \mathrm{g} / \mathrm{m}^{3}$ beyond which $\mathrm{SO}_{2}$ concentrations are considered dangerous. EC and $\mathrm{WHO}$ also provide short-term ten minute averages of 350 and $500 \mu \mathrm{g} / \mathrm{m}^{3}$ respectively. However, with the uncertainty in being able to constrain both the magnitude and temporal variation in $\mathrm{SO}_{2}$ fluxes it is felt that the daily average is the most appropriate limit to use as an initial assessment of $\mathrm{SO}_{2}$ hazard. The $\mathrm{SO}_{2}$ thresholds are used here as points of reference for modelling purposes and are conservative values that have been defined with reference to a general population undertaking everyday activities. Thus they may not be appropriate to an emergency situation; more specific health risk assessments will be needed in case of an eruption, where air quality monitoring and health surveillance of the population will be a requirement.

For the objectives of this study, we identified nine locations on the island that represent key centres of population or critical infrastructure (Fig. 1 and Table 6).

\section{Ground ash hazard}

The results of the ash fall modeling can be displayed in several ways to help elucidate the hazard; perhaps the most useful are exceedance probability maps and exceedance curves for individual events. Assuming that each simulation run for any given scenario is equally probable (i.e. probability $=1 /$ number of simulations), the exceedance probability is calculated for each grid cell by summing the probabilities from all simulations for the given scenario that exceed the loading threshold at that grid cell. In this way exceedance probability maps or locationspecific curves highlight patterns in possible wind conditions at the time of a future eruption. Here, we discuss the results from our two defined scenarios: a most likely weak plume and a largest considered sub-Plinian eruption. Primary ash fall hazard results are shown from TEPHRA2 outputs but for the most likely scenario they are also compared with those from VOL-CALPUFF.

\section{Most likely scenario}

The ground ash hazard assessment for a long-duration weak plume event shows that ash hazard is strongly affected by wind direction, with relatively high ash hazard in the south and east of the island, notably at the Port and Akrotiri, and very low hazard at Oia in the north. For each of the six eruption scenario variants (see Scenario identification and Table 3), Fig. 4 shows the average number of days in the total eruption scenario that the daily ash load exceeds $1 \mathrm{~g} / \mathrm{m}^{2}$, considered to be approximately equivalent to the onset of ash fall and reduced air quality. Such ash events are forecast to be about 10 times more likely at the Port than at Oia (Fig. 4).

When considering individual events for the typical Santorini Weak case, the probability that the $1 \mathrm{~g} / \mathrm{m}^{2}$ threshold is exceeded at the Airport changes from 20 to $50 \%$ for plume heights from 0.5 to $3 \mathrm{~km}$ (Fig. 5). If $35 \%$ is taken as representative then under the typical Santorini Weak case ash is produced $7.6 \%$ of the time so that the expected periods when ash approaches or exceeds suspended concentrations would be about $3 \%$ of the eruption duration, or a 1 in 30 chance of flights being disrupted during a two year eruption. Similar relationships to those seen at the Airport (Fig. 5) are observed in the results for other locations. Increased plume heights produce higher probabilities at all study sites, reflecting the greater reach of the ash. Ash loading hazard that assumes the 'Santorini Weak' case (plume affected by wind) exceeds that of the 'Santorini Strong' (plume unaffected by wind) case by up to a factor of 4 (Figs. 4 and 5), reflecting the increased mass of erupted ash (Table 3). This highlights the underestimation of ash hazard yielded by assessments that do not take into account the effects of wind on weak to moderate intensity eruptions. The effect of aggregation, simulated here by increasing the grain sizes, is to reduce hazard (Figs. 4 and 5); this is due to the settling velocity distribution being coarser so that more mass falls out close to the volcano. As plume height increases, the effect of aggregation is 
Table 6 Names and description of key population centres and critical infrastructure, with their location relative to the Kameni islands, the most likely source for a future eruption of Santorini

\begin{tabular}{|c|c|c|}
\hline Name & Description & $\begin{array}{l}\text { Distance and bearing } \\
\text { from Nea Kameni }\end{array}$ \\
\hline Thera (Fira) & The modern capital of Santorini and a key tourist centre & $3.5 \mathrm{~km}$ east-northeast \\
\hline Santorini airport & A military and civilian airport receiving international flights & $7 \mathrm{~km}$ east \\
\hline Port Athinios & The main harbour serving passenger and cargo ships & $3.5 \mathrm{~km}$ southeast \\
\hline Pyrgos & Tourist village in the centre of the island & $5.5 \mathrm{~km}$ southeast \\
\hline Kamari & $\begin{array}{l}\text { Coastal settlement to the southeast of the island built after the } \\
\text { devastating earthquake of } 1956\end{array}$ & $8.5 \mathrm{~km}$ east-southeast \\
\hline Perissa & Coastal settlement to the southeast of the island & $9 \mathrm{~km}$ southeast \\
\hline Akrotiri & $\begin{array}{l}\text { An important archaeological site where a Minoan settlement was } \\
\text { buried under pyroclastic deposits during the Thera eruption in } \\
\text { approximately } 1630 \mathrm{BC}\end{array}$ & $5 \mathrm{~km}$ south \\
\hline Therassia & The smaller island forming the remains of the caldera wall & $5.5 \mathrm{~km}$ northwest \\
\hline Oia & A relatively large town of more than 4000 inhabitants & $6.5 \mathrm{~km}$ north-northwest \\
\hline
\end{tabular}

reduced because the stronger higher plumes, particularly in stronger winds, have similar reach for both assumed grain size distributions. This suggests a lower sensitivity to assumed grain size distribution for the more intense eruptions. Grain size is poorly constrained at Santorini because of the lack of ash grain size studies for historic Santorini eruptions and this finding suggests that grain size studies should prioritise fallout from weaker ash emissions. 'Clustering' of events, achieved by reducing the inter-event times according to an increased Poisson rate parameter, leads to more days with higher concentrations; for distinct periods of explosivity within this eruption scenario variant, the more frequent explosive activity invoked by clustering of events may lead to a greater disruption of activities on the island, especially as more closely spaced events will limit the extent to which manual or environmental ash removal can occur. Consequences of this for aviation and the tourism industry and for repeated clean-up activities may be significant.

For a long duration event, as may be expected with the most likely scenario, ash falls may cumulate from multiple events over weeks, months or years and this will lead to much greater accumulations than for the individual events. Plotting the total ash accumulations over two years therefore provides an estimate of the maximum loading; erosion, wind re-distribution, rain and clean-up operations will act to reduce this load in uncertain ways. Figures 6 and 7 show the same results in three different ways to elucidate different aspects of the hazard. Figure 6a shows the hazard spatially as the cumulative deposit with 0.5

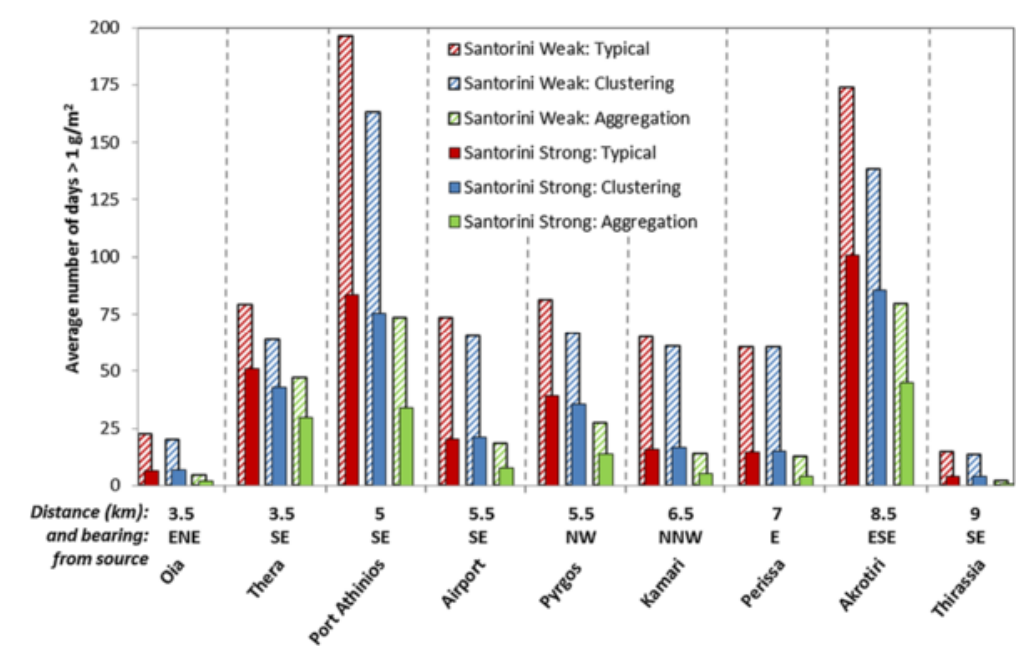

Fig. 4 The average number of days, for the six scenario variants identified in Table 3, during the course of the one or two-year simulated most likely eruptions, as computed by the TEPHRA2 model, that the daily deposit exceeded $1 \mathrm{~g} / \mathrm{m}^{2}$, approximately related to the onset of ash fall and reduced air quality. Santorini Weak cases where no aggregation or event clustering is simulated ('Typical') result in the highest hazard: approximately two days in every week at Port Athinios 


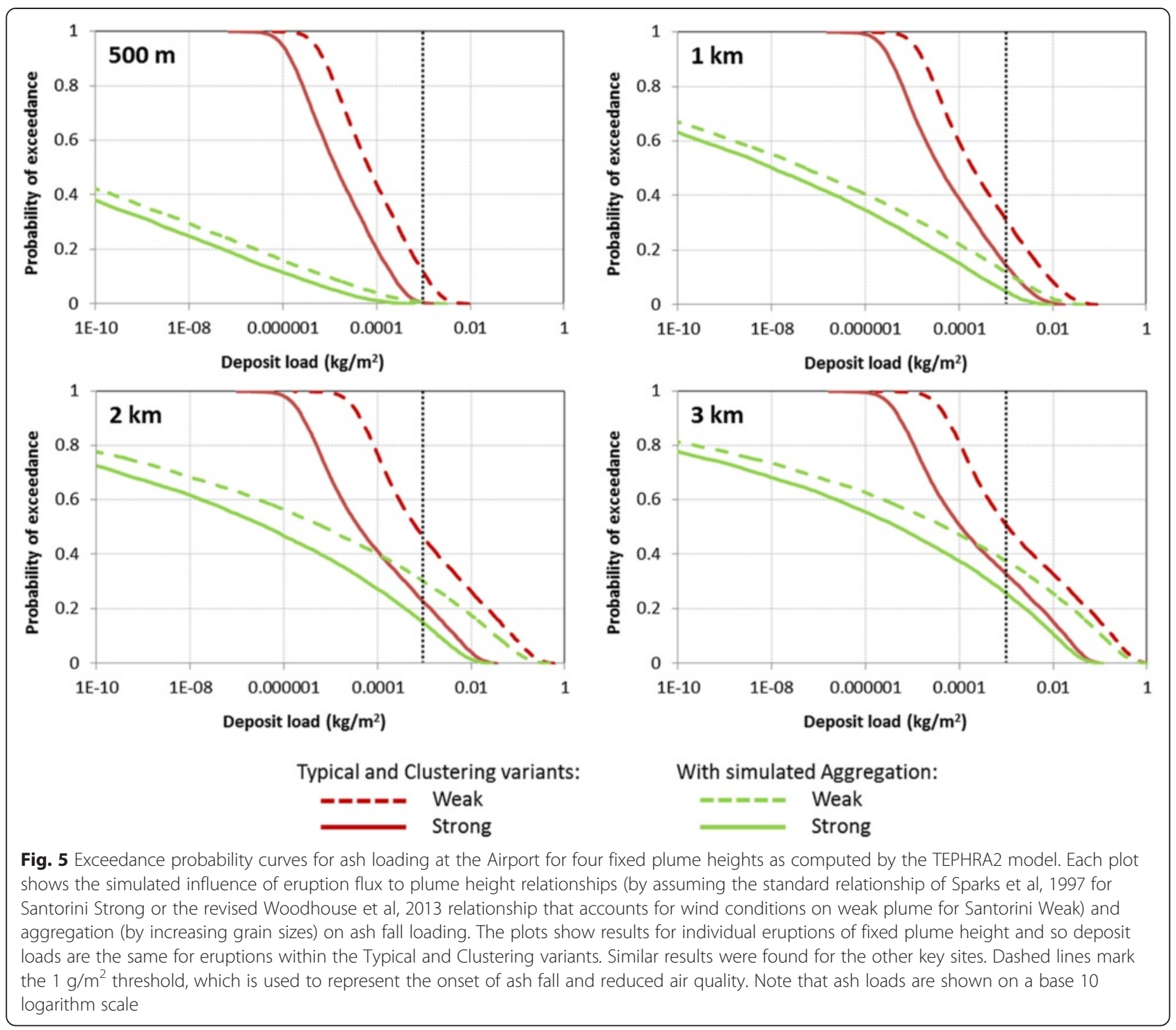

exceedance probability $(50 \%$ probability of being exceeded), while Fig. $6 \mathrm{~b}$ shows the probability of the cumulative deposit exceeding $10 \mathrm{~kg} / \mathrm{m}^{2}$ (an exceedance probability map). Fig. 7 shows the probability of exceeding a range of cumulative ash loads at each of the nine sites of interest (an exceedance probability curve). Even considering a maximum cumulated load, the probability of reaching conditions for collapse of very weak roofs $\left(\sim 100 \mathrm{~kg} / \mathrm{m}^{2}\right)$ is negligible on the island. These results further indicate that, in the event of a future longduration eruption, much of the ash will fall out in the caldera and deposits on island will be quite thin, with lowest ash hazard likely in the north of the island at Oia and relatively high ash hazard at Thera, the Port and Akrotiri.

\section{Comparison of model outputs}

TEPHRA2 is an open-source, simple advection-diffusion model that assumes an instantaneous release of the erupted mass and steady-state atmospheric conditions. The code can run in minutes on a desktop computer, making it ideal for the rapid hazard assessment and simulation of multiple ash fall scenarios described here, particularly at medium to distal locations. We compare the ground ash hazard results above with an equivalent assessment using the VOL-CALPUFF model. VOLCALPUFF can model a continuous release of mass during an eruption and account for changes in wind condition with distance from source and with time through the eruption. It is able to calculate ash concentration in the air as well as loading on the ground, with 


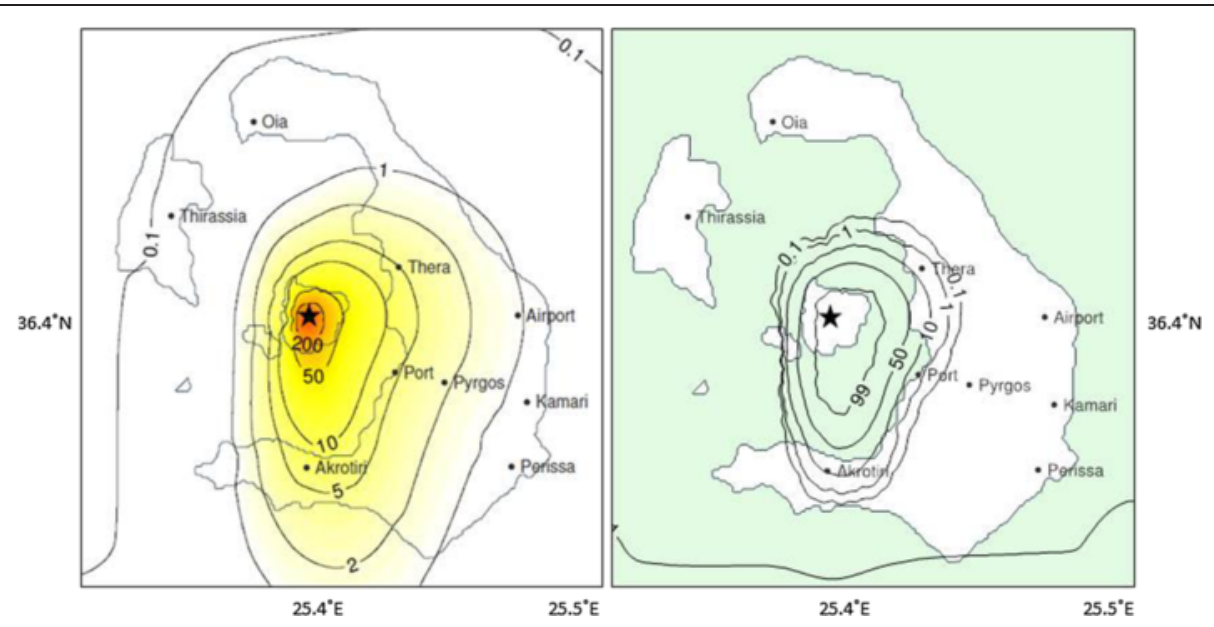

Fig. 6 Probability maps that represent total ash accumulation on the ground over a most likely eruption scenario as computed by the TEPHRA2 model. The same results are shown in two different ways: a) the 0.5 exceedance probability (50 \% probability of being exceeded) cumulative deposit (in $\mathrm{kg} / \mathrm{m}^{2}$ ) in each grid cell; and b) the probability (as a percentage) of the cumulative deposit exceeding $10 \mathrm{~kg} / \mathrm{m}^{2}$ over the simulated eruption. A Santorini Weak typical case is assumed. In reality, these probabilities represent an upper bound because ash will be removed or remobilised by natural (rain, wind) and manual clean-up operations. The black star marks the simulated vent location

particular accuracy at proximal to medium locations. VOL-CALPUFF samples from a 10 year wind dataset sourced from NCEP/NCAR; statistical analysis of this dataset relative to the 20 year ECMWF data used with TEPHRA2 shows little variation between the two sources (Fig. 2). The two models differ fundamentally with VOLCALPUFF (and other coupled meteorological transport models) having greater input requirements (due to the explicit consideration of the dynamics of the source plume) and more detailed outputs, but longer runtimes than simpler advection-diffusion models like TEPHRA2. Few direct comparisons of the models exist and therefore, comparing the models like-for-like provides a representative measure of model uncertainty in forecasting potential impact and allows us to identify areas of impact for which we have the greatest confidence (Fig. 8). Given the computational requirements of VOL-CALPUFF, only one scenario variant (the Typical Weak) could be modelled and we compare the results of these runs with the equivalent outputs from TEPHRA2 here.

For the simulated most likely weak plume eruption scenario, Fig. 8 shows a comparison between the outcomes of the two models in terms of exceedance probabilities with reference to a ground load of $1 \mathrm{~kg} / \mathrm{m}^{2}$. The maps show a high level of agreement, particularly for the higher probabilities and so the implications for

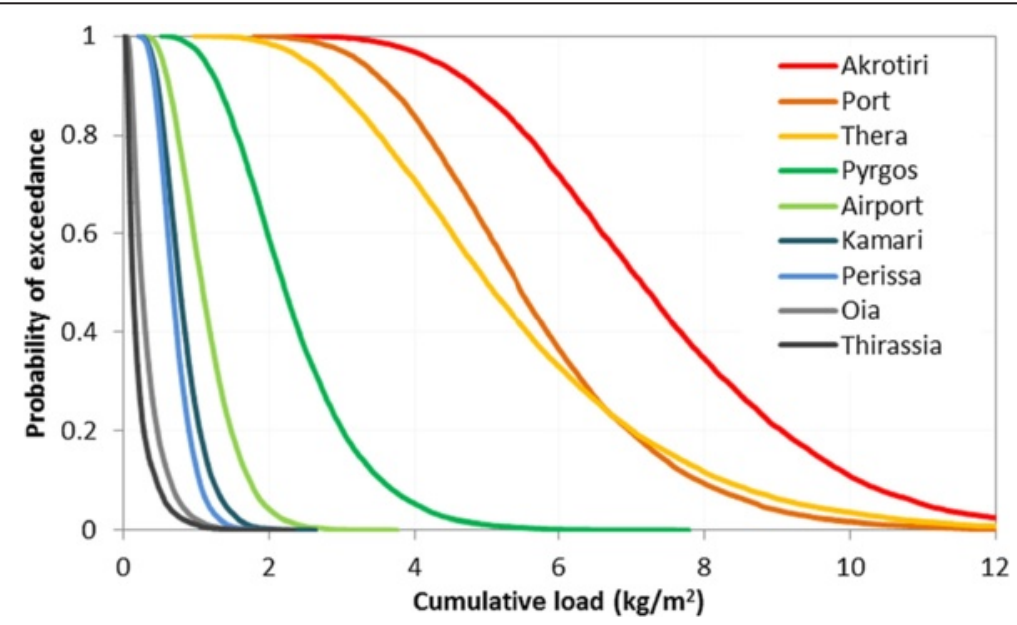

Fig. 7 Exceedance probability curves for cumulative ash load at each of the nine key sites of interest, as computed by the TEPHRA2 model for a most likely eruption scenario. These curves represent another way of displaying the same results as in Figs. 4 and 6 (total ash accumulation from a Santorini Weak typical case). In reality, these probabilities represent an upper bound because ash will be removed or remobilised by natural (rain, wind) and manual clean-up operations. The legend shows sites in order of decreasing hazard 


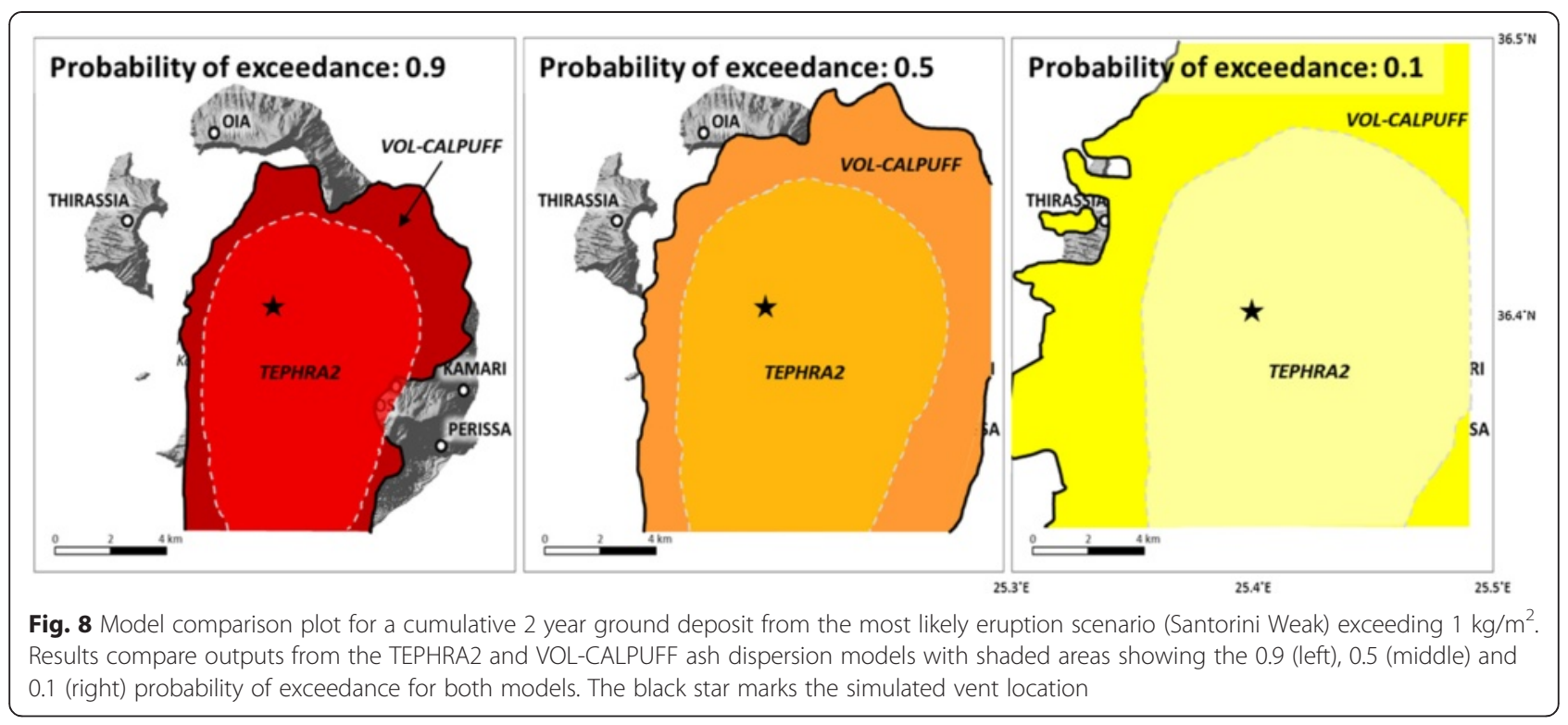

emergency management planning are similar. In particular, both models show the highest hazard across the southern part of the island. At loads of $1 \mathrm{~kg} / \mathrm{m}^{2}$, VOLCALPUFF shows comparatively larger affected areas, but this trend is reversed at very small loads $\left(<0.01 \mathrm{~kg} / \mathrm{m}^{2}\right)$, particularly for weaker events (1 km plume: Fig. 9). Two main factors are thought to describe this outcome. First, the use of hourly meteorological data with VOLCALPUFF, which allows for wind field variations with time and space and has a strong influence on the ash dispersal process. In fact, even small changes in wind direction over time will affect ash deposition, particularly in a prolonged eruption. This is confirmed by the fact that the weaker $(1 \mathrm{~km})$, but longer (Table 3$)$, events show the largest differences when VOL-CALPUFF and TEPHRA2 outputs are compared (Fig. 9). On the other hand TEPHRA2, as any other pure Eulerian advectiondiffusion code, is relatively more diffusive at source and as a consequence affects larger areas with lower mass loadings. This implies that, relative to VOL-CALPUFF,
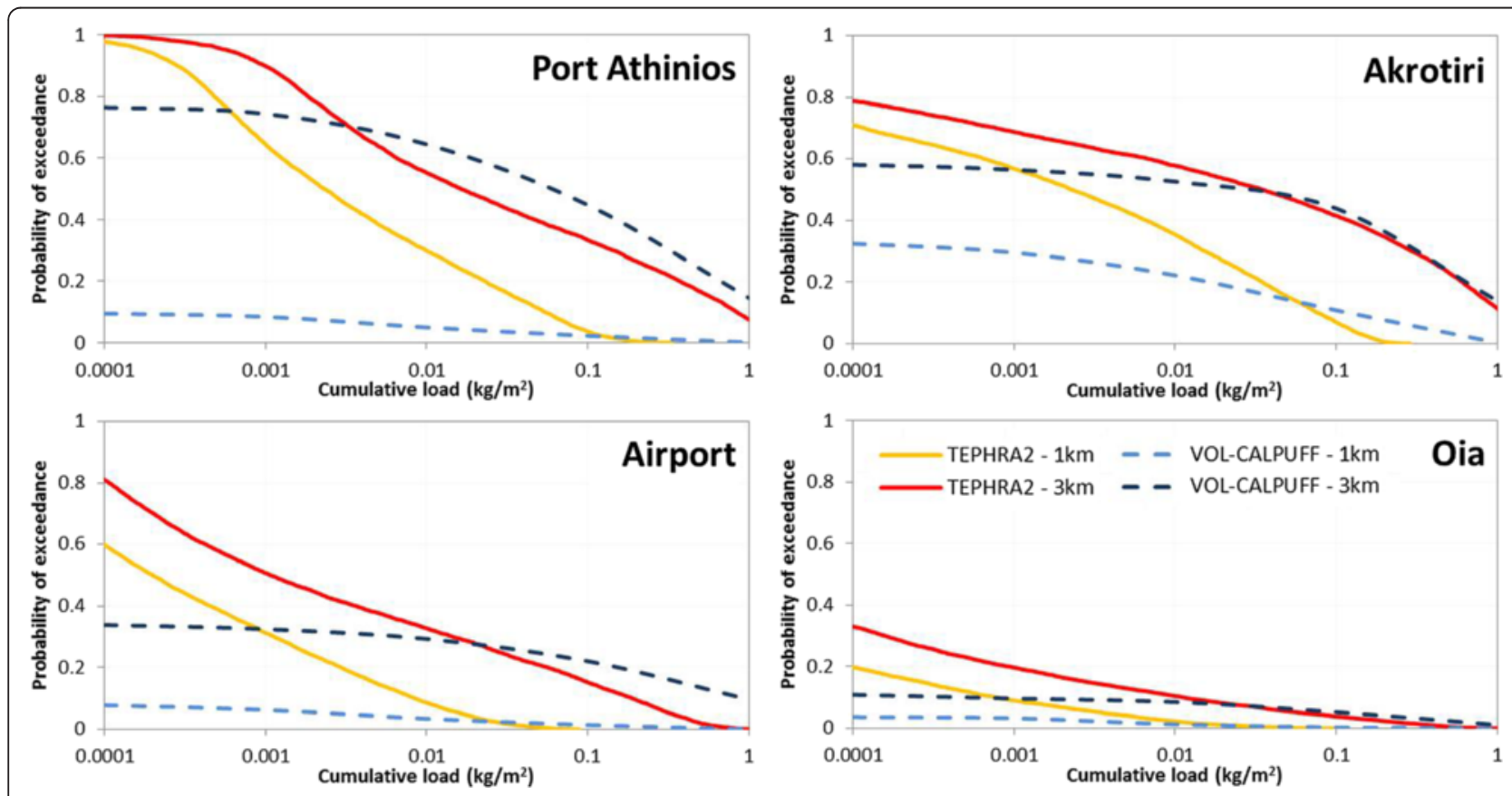

Fig. 9 Model comparison for four key locations assuming fixed column heights of $1 \mathrm{~km}$ and $3 \mathrm{~km}$ and typical Santorini Weak eruption parameters. Note that ash loads are shown on a base 10 logarithm scale 
more distal locations will be affected by smaller deposits, but that the probability of reaching higher tephra loads in more proximal areas will be lower, as shown in Figs. 8 and 9. In addition to the wind variability over time and plume diffusivity, the different wind datasets employed by the two models may also play a role in differences in model output: at lower altitudes $(<1 \mathrm{~km})$, the ECMWF data used by TEPHRA2 has comparatively faster wind speeds than the NCEP/NCAR data used by VOL-CALPUFF (Fig. 2), which may help to compensate for the less lateral dispersal in the plume. At higher altitudes $(\sim 3 \mathrm{~km})$, the wind data are more comparable, although ECMWF reanalysis data show slightly more dominant westerly winds than NCEP/NCAR (Fig. 2). These effects (wind variability and less diffusivity for VOL-CALPUFF) are more evident when a single fixed height scenario is assumed, and are masked within the cumulative 2-years long scenario. Nevertheless, the overall similarity in results is comforting and suggests that for the purposes of rapid emergency management planning a simple advection-diffusion model such as TEPHRA2 can capture the first-order distribution of ash fall hazard locally.

\section{Largest considered scenario}

The results of the TEPHRA2 sub-Plinian ground ash hazard model are shown in Figs. 10 and 11 as exceedance probability maps and site-specific curves. In this case there is a possibility of roof collapse occurring, although it is small. For weak roof structures at Thera (old or poor condition tiles and lightweight metal sheeting), there may be approximately a $10 \%$ to $15 \%$ chance of roof collapse $\left(\geq 200 \mathrm{~kg} / \mathrm{m}^{2}\right)$. For the dominant roof type on Santorini (reinforced concrete slab) the chance of roof collapse is negligible (a few \%) (following Spence et al, 2005), although the hazard could approximately double if there was rain during or shortly after the eruption because of the increased load from saturated ash (Macedonio and Costa, 2012). Local disruption to aviation is certain and might extend tens or even hundreds of kilometres away in regional airspace (although a quantitative assessment of this is outside the scope of this study). Dominant northwesterly and westerly winds above 1 to $2 \mathrm{~km}$ altitude are most likely to control the dispersal of a sub-Plinian plume and so at lower thickness thresholds (Fig. 10a) areas to the south and east are subject to highest hazard, as for simulated weak plumes. With increasing ash load threshold (Fig. 10b), higher hazard is orientated towards the south because lower altitude winds become important for particles that fall out more quickly and for the increased ash amount. Overall, probabilities of ash hazard at Oia and Therassia are much lower than in the south and east (Figs. 10 and 11), with only a 5 to $10 \%$ chance of loads exceeding $10 \mathrm{~kg} / \mathrm{m}^{2}$, approximately equivalent to $10 \mathrm{~mm}$ deposit. As with the most likely eruption scenario, this is predominantly a consequence of local wind conditions.

\section{Airborne ash hazard}

The presence of an international airport just $7 \mathrm{~km}$ to the east of the most recent vent and the importance of Santorini as a tourist destination made it important for this rapid

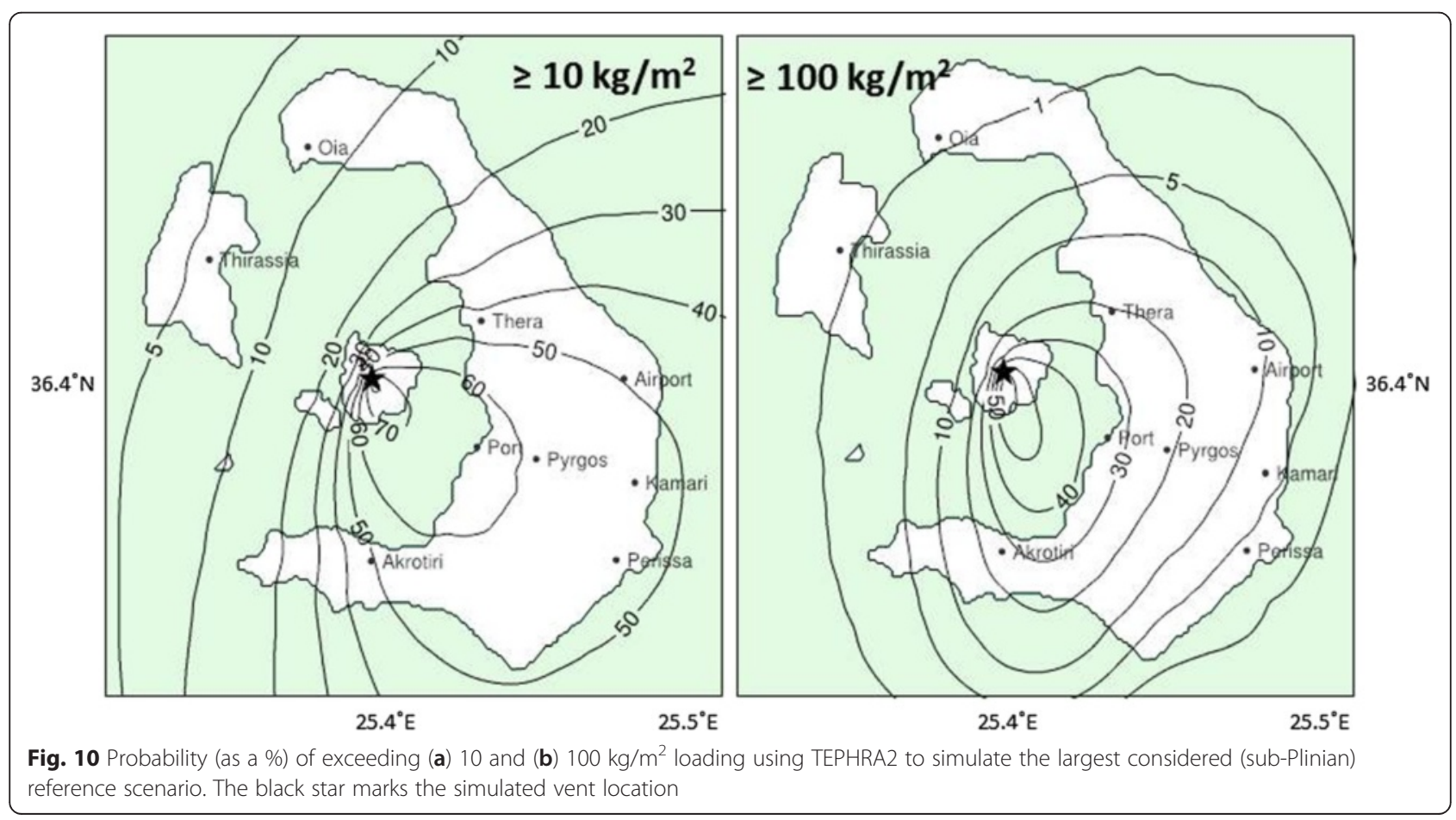




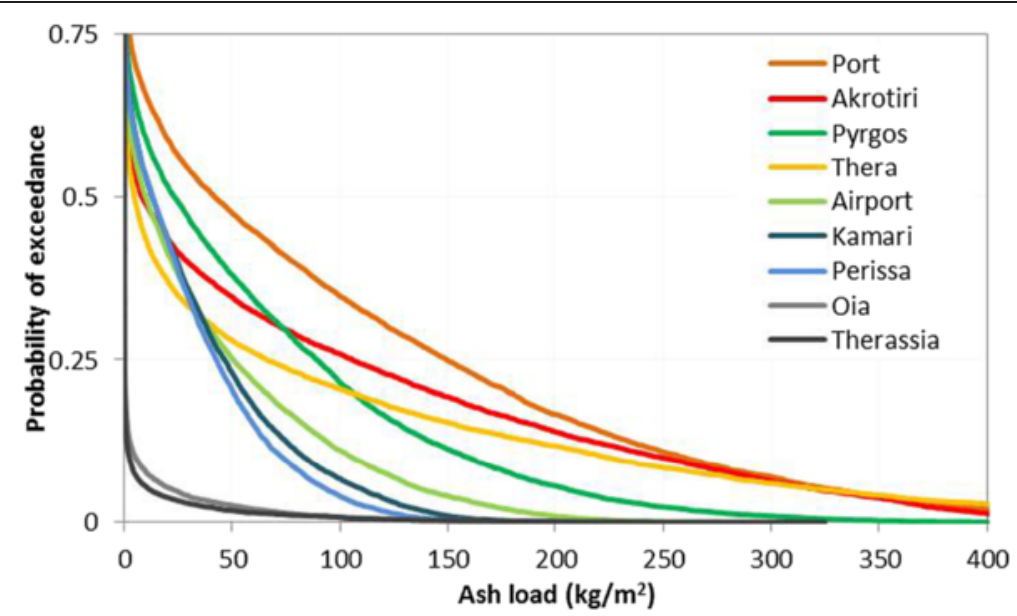

Fig. 11 Exceedance probability curves for ash loading at each of the key sites on Santorini following the largest considered scenario. The legend shows sites in order of decreasing hazard at the $100 \mathrm{~kg} / \mathrm{m}^{2}$ threshold. Sites to the North and West (Oia and Therassia) show very low hazard relative to sites East and South of the volcano, as computed by the TEPHRA2 model

study to also consider the potential ash concentration at altitude. Using VOL-CALPUFF, we generated exceedance probability maps of aerial ash concentration at $1000 \mathrm{~m}$ above ground level for two thresholds for aviation safety at that time: 2 and $0.2 \mathrm{mg} / \mathrm{m}^{3}$. We also used VOL-CALPUFF to assess ash concentration at ground level because of its important with regard the presence of fine ash that could be inhaled by the population (assumed here to be 15 micron sized particles or less, as a proxy for $\mathrm{PM}_{10}$ ). We discuss results for the most likely weak plume eruption scenario here.

\section{Most likely scenario}

Reference concentration thresholds were exceeded with very low probabilities in the aerial space around the Airport (Fig. 12); only the 2 and $3 \mathrm{~km}$ plume scenarios were able to bring suspended ash towards the east at an altitude of $1000 \mathrm{~m}$ a.g.l. Assuming a fixed plume height of $3 \mathrm{~km}$, ash concentrations of $2 \mathrm{mg} / \mathrm{m}^{3}$ or greater (Commercial aviation Enhanced Procedure Zone) may be expected with a probability of less than $5 \%$. Smaller fixed plume height scenarios of $0.5 \mathrm{~km}$ affected the atmosphere at altitudes of a few hundred metres in the southern part of the island but did not extend to the Airport.

In contrast to the estimated ground deposit hazard, fixed plume height exceedance probability curves for ash concentrations at ground level show hazard (probabilities associated with the amount of suspended fine particulate matter) at the nine study sites to be higher for smaller events, i.e. lower plume heights, than for larger events (Fig. 13). Barsotti et al. (2010) have suggested that higher plume heights, releasing larger amounts of ash higher into the atmosphere, support the transport of the finer portion of ash farther from the vent. At Santorini, stronger wind speeds at altitudes above 1 to $2 \mathrm{~km}$ (Fig. 2) will exacerbate this situation, although larger amounts of fine material may be associated with stronger events meaning that the difference in hazard close to source remains small. Areas to the south (Akrotiri) are expected to experience highest hazard with respect to the other locations considered for plumes of $2 \mathrm{~km}$ or lower. Vice versa, enhanced dispersion and highest hazard towards the east (Port, Thera) are expected with a $3 \mathrm{~km}$ plume. These results suggest that 10 to $50 \%$ of events with plume heights greater than $1 \mathrm{~km}$ will cause conditions in the south and east of the island that could raise health concerns (Fig. 13). However, environmental conditions will strongly influence the level of fine ash exposure and associated impact on air quality. For example, frequent rain will reduce airborne ash concentrations while resuspension of ground ash deposits through wind, traffic and/or human activities like clean-up will increase airborne ash concentrations, leading to a potentially significant reduction in air quality (e.g. Thorsteinsson et al, 2012).

\section{$\mathrm{SO}_{2}$ gas hazard}

Significant health effects related to volcanic gases were observed during the 1866 eruption of Santorini (Dakoronias, 1879). Thus we made preliminary estimates of future $\mathrm{SO}_{2}$ gas concentrations around the island. We stress that $\mathrm{SO}_{2}$ fluxes from typical Santorini eruptions are poorly constrained and large fluctuations in $\mathrm{SO}_{2}$ flux are likely during eruption. Measurements at other arc volcanoes suggest that these variations can approach an order of magnitude either side of the long-time average flux and that fluctuations can be on time scales of hours to many months. In the event of a future eruption at Santorini, the collection of $\mathrm{SO}_{2}$ flux data will be critical in evaluating the gas hazard more accurately than is possible here. In particular, the vulnerability of at-risk groups in the population 


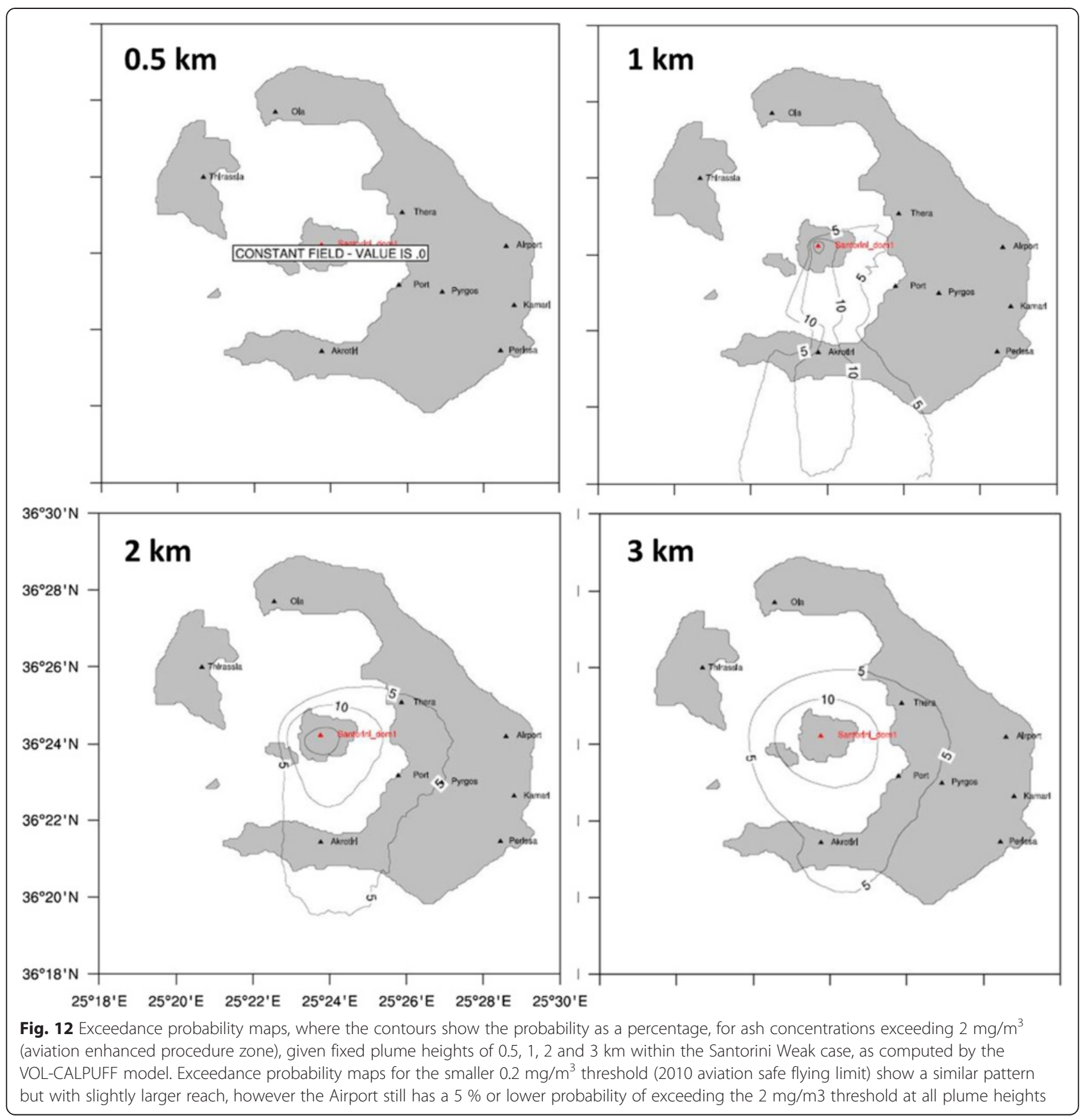

will need to be assessed in the light of measured peaks of $\mathrm{SO}_{2}$ of short duration (15 min measurements) and possible synergistic health impacts from combined elevated fine ash particulate and $\mathrm{SO}_{2}$ levels, amongst other factors not appropriate to consider here. The hazard modelling shows that the effects on air quality in the scenarios outlined are not trivial and health impact assessments will be a priority in future preparedness measures and actual crisis management. Expert medical and air pollution expertise should be sought.
The mean number of days (within a two-year degassing period) that $\mathrm{SO}_{2}$ concentrations exceed air quality guideline thresholds set out by the World Health Organisation (WHO) and European Commission (EC) for the reference eruption scenarios are shown in Table 7 . Results suggest that exposure to reduced air quality $\left(>20 \mu \mathrm{g} / \mathrm{m}^{3}\right)$ during an eruption is likely to be widespread and frequent across the island and Thera, the capital of Santorini and an important tourist site, may experience gas concentrations $>125 \mu \mathrm{g} / \mathrm{m}^{3}$ approximately 

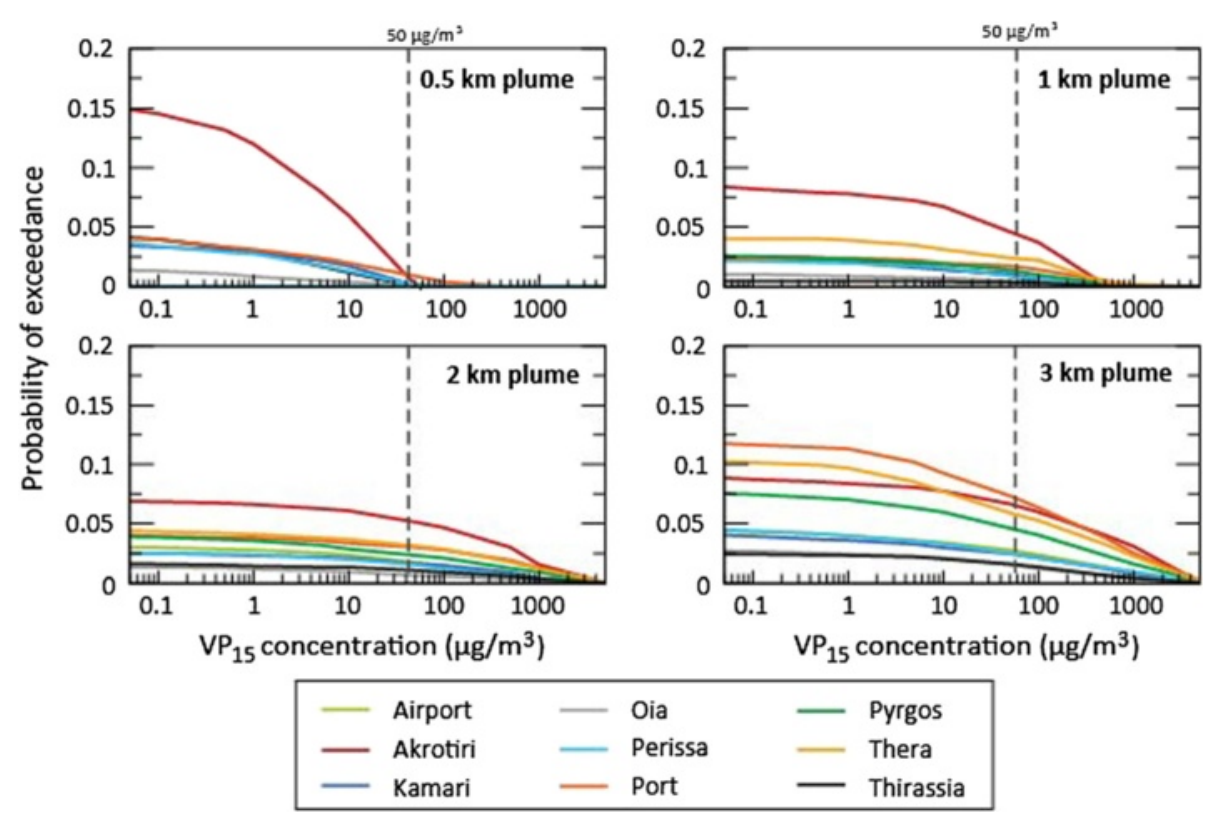

Fig. 13 Exceedance probability curves for VP 15 ash concentrations at the key nine sites, as computed by VOL-CALPUFF for individual plume heights within the Santorini Weak case for the mostly likely eruption scenario. The WHO daily threshold for good air quality $\left(50\right.$ $\mu \mathrm{g} / \mathrm{m}^{3}$ ) is shown by the vertical line. Note the maximum value of 0.2 on the y axis and that ash loads are shown on a base 10 logarithm scale

one day in every eleven (Fig. 14 and Table 7). However, as with ash, the gas hazard is strongly influenced by wind conditions, and the greatest hazard, in terms of the probability that $\mathrm{SO}_{2}$ concentrations in any one day will exceed the EC threshold of $>125 \mu \mathrm{g} / \mathrm{m}^{3}$, can be found to the south at Akrotiri, with an approximately $5 \%$ probability during the 200 tons/day scenario and $25 \%$ during the 800 tons/day scenario. The lowest hazard is to the north at Oia (<2 \%) (Fig. 14). The two emission scenarios show significantly different probabilities more than $4 \mathrm{~km}$ from the vent (i.e. all sites except Thera and the Port), particularly for exposure to gas concentrations $>125 \mu \mathrm{g} / \mathrm{m}^{3}$. This provides further impetus for collecting measurements that can constrain $\mathrm{SO}_{2}$ flux estimates in the event of an eruption. More studies are required to see what effect a stronger plume than that simulated here would have for the hazard at each of the key sites.

\section{Conclusions and emergency management implications}

Here we have summarised the main outcomes of two parallel coordinated investigations, which aimed to provide scenario-based probabilistic ash and gas hazard assessments for Santorini volcano during the unrest of

Table 7 Mean percentage of days (in a two year period of degassing activity) that $\mathrm{SO}_{2}$ concentrations exceed air quality guidelines and standards, given 200 tons/day and 800 tons/day emission scenarios

\begin{tabular}{|c|c|c|c|c|}
\hline \multirow[b]{2}{*}{ WHO limits: } & \multicolumn{2}{|l|}{200 tons $\mathrm{SO}_{2} /$ day } & \multicolumn{2}{|l|}{800 tons $\mathrm{SO}_{2} /$ day } \\
\hline & WHO AQG - 20 $\mathrm{\mu gm}^{-3}$ & EC AQG $-125 \mu \mathrm{gm}^{-3}$ & WHO AQG - 20 $\mathrm{\mu gm}^{-3}$ & $\mathrm{EC} \mathrm{AQG}-125 \mathrm{\mu gm}^{-3}$ \\
\hline$\overline{\text { Oia }}$ & 6 & 0.3 & 8 & 2 \\
\hline Thera (Fira) & 16 & 4 & 17 & 9 \\
\hline Port Athinos & 20 & 3 & 20 & 6 \\
\hline Airport & 15 & 0.4 & 22 & 5 \\
\hline Pyrgos & 17 & 0.8 & 22 & 10 \\
\hline Kamari & 14 & 0.3 & 21 & 4 \\
\hline Perissa & 13 & 0.1 & 21 & 3 \\
\hline Akrotiri & 37 & 4 & 43 & 23 \\
\hline Therassia & 4 & 0.3 & 5 & 1 \\
\hline
\end{tabular}

The lower threshold $\left(20 \mu \mathrm{g} / \mathrm{m}^{3}\right)$ represents Air Quality Guidelines (AQG) stated by the World Health Organisation, below which air quality is deemed to be good, and the upper threshold $\left(125 \mu \mathrm{g} / \mathrm{m}^{3}\right)$ statutory Air Quality Guidelines (AQG) set by the European Commission (EC), which are considered dangerous for periods of $24 \mathrm{~h}$ or more 


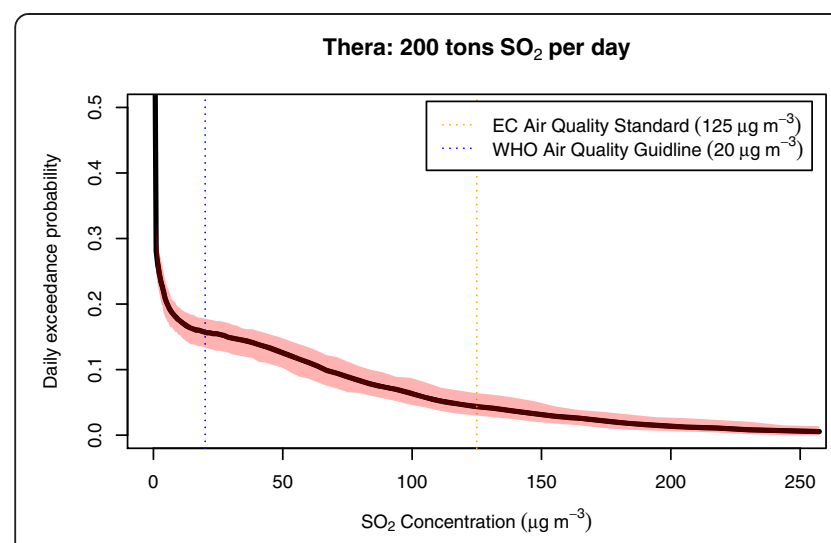

Thera: 800 tons $\mathrm{SO}_{2}$ per day
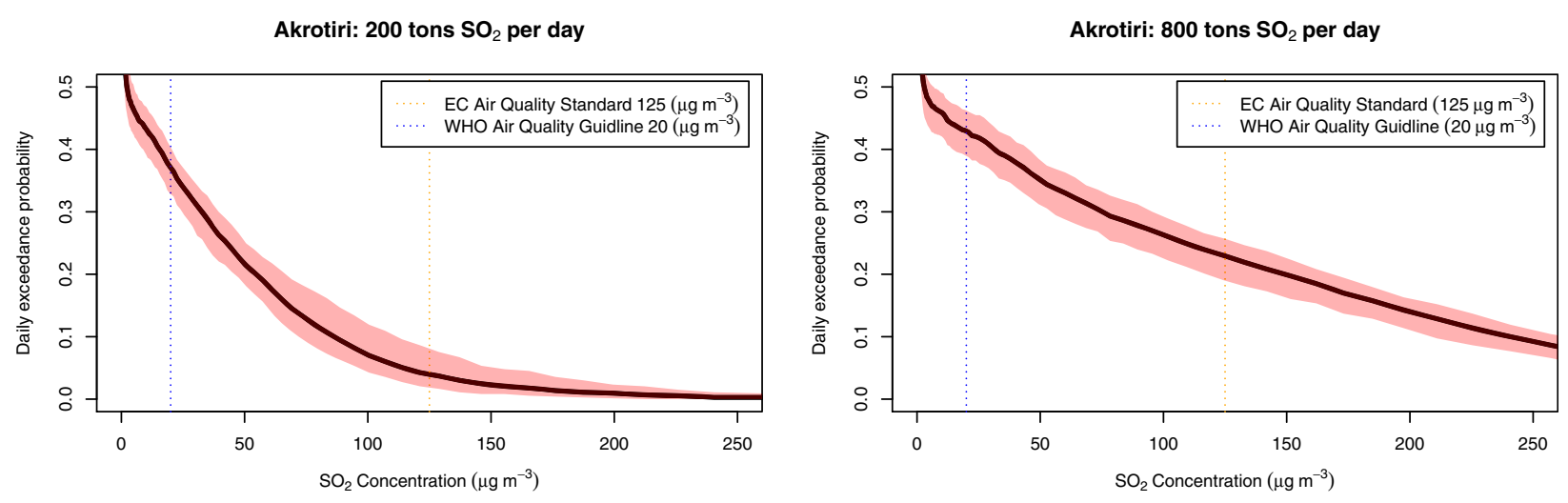

Oia: 200 tons $\mathrm{SO}_{2}$ per day
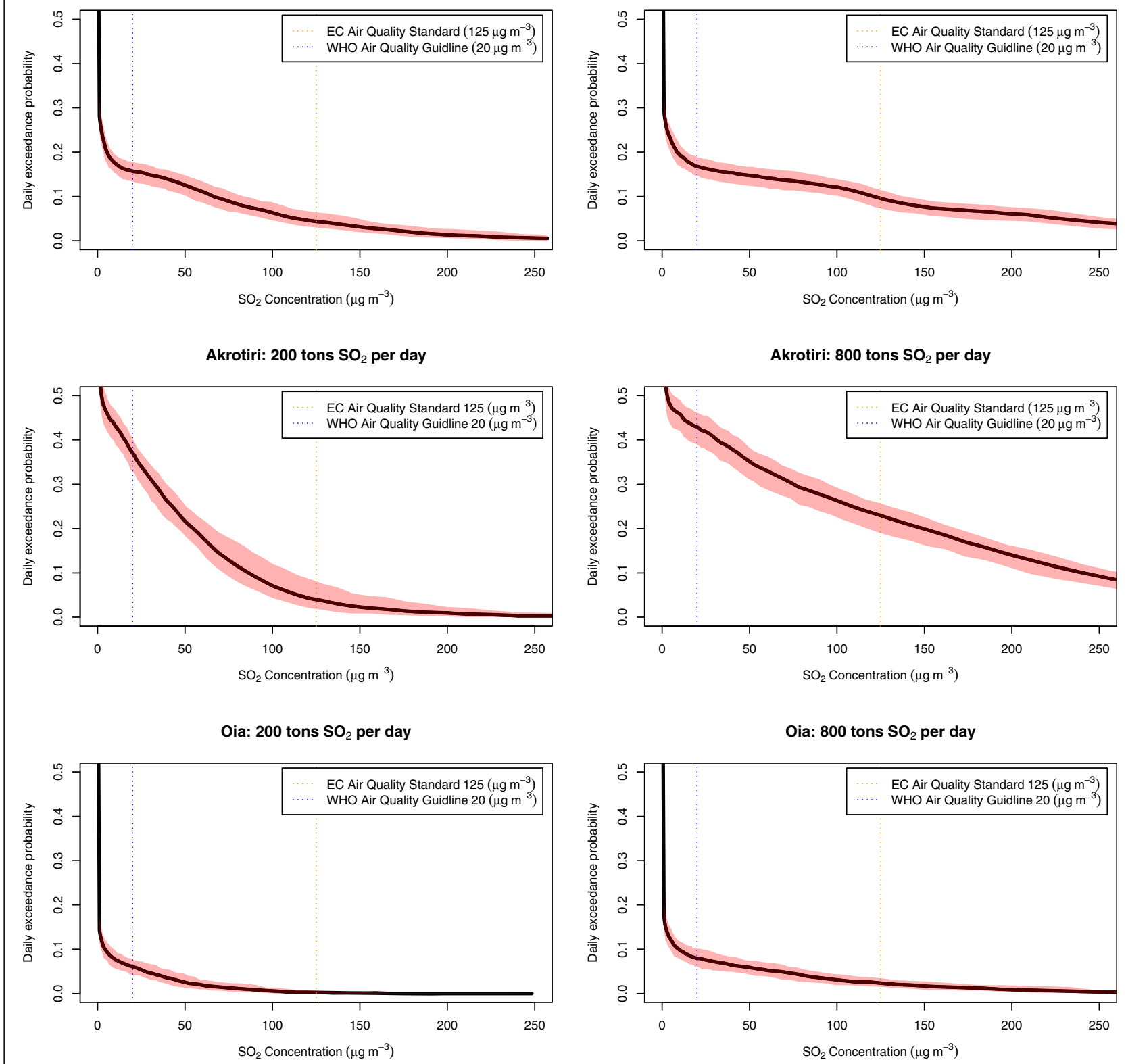

Fig. 14 Daily median exceedance probability curves (shaded areas represent the interval between the 0.05 and 0.95 probability of exceedance, based on sampling 100 two-year simulations) for $\mathrm{SO}_{2}$ gas concentration at Thera (upper), Akrotiri (middle) and Oia (lower) as computed by the AERMOD model. Scenarios of 200 tons $\mathrm{SO}_{2}$ /day (left) and 800 tons $\mathrm{SO}_{2} /$ day (right) are shown as are the $\mathrm{EC}$ and WHO air quality thresholds for dangerous (orange dashed line: $125 \mathrm{\mu g} / \mathrm{m}^{3}$ ) and reduced (blue dashed line: $20 \mathrm{\mu g} / \mathrm{m}^{3}$ ) air quality, respectively. Note the maximum value of 0.5 on the $y$ axis. As with ash hazard, these plots suggest that Oia is likely to experience lesser impact than the rest of the island

2011-2012. The studies were carried out within a short timeframe and in the face of significant uncertainty in order to inform emergency management and planning for a future eruption. As such, they exemplify a rapid emergency hazard assessment undertaken in an emergency to provide a first-order indication of likely hazard.

The results of the two independent emergency studies both confirm that ash and gas hazard is likely to be of concern if an eruption of Santorini occurs. That the studies were carried out independently and were of broad agreement strengthens our confidence in the hazard outputs. Fixed plume height exceedance probability maps and curves of ash loading and airborne ash were found to represent the more useful tool as they give an indication of hazard, and therefore required management actions, associated with individual scenarios. Ash 
and gas hazards are relatively high at key population centres in the south and east such as Thera and Pyrgos, and at transport hubs, notably the Port and Airport, principally as a consequence of the dominant wind directions. However, the level of hazard is also influenced by the intensity of the event, the altitude over which the volcanic material is released, distance from the vent and the occurrence of precipitation. The north of the island has much lower ash and gas hazard, and therefore is the logical place to develop emergency services, such as a volcano observatory, civil defence headquarters and medical facilities. For the most likely eruption scenario (i.e. long-duration and intermittent ash production from weak plumes), ash loading is expected to be too small for roof collapse to be a threat. However, ash and gas will be an intermittent threat to air quality, critical infrastructure and aviation.

For the first time, probability maps of aerial ash concentration have been created for Santorini. Suspended ash levels in a most likely weak plume scenario are calculated to be at levels likely to be of concern for the aviation industry, it seems probable that the Airport will be affected for some ash events and also that operations at the Port may be disrupted. Volcanic ash plumes will be persistent and largely unpredictable so that cancellation or diverting of flights and temporary grounding of aircraft may happen more frequently than actual ash concentrations may require. In particular, disruption of international flights and the risk of adverse impacts for cruise ships anchoring in the southern and eastern portions of the caldera during the summer months, e.g. through passenger respiratory issues or corrosion to paintwork, has large potential economic impact for the important tourism industry. Modelled ash and gas concentrations exceeded current World Health Organisation thresholds for safe air quality standards more than once a week (15 to $20 \%$ ). People may be affected for periods of hours to days and such conditions will occur repeatedly during an eruption. This supports historic observations of health issues associated with the 1866 to 1870 eruption of Santorini. However, potentially harmful fluctuations in gas or ash emissions, wind directions and/or resuspension of ash by wind are not captured in this modelling and health advice should be taken from medical experts. Adequate supplies of dust masks are recommended for citizens and tourists and regular monitoring of the air quality (ash and gas concentrations) during the eruption is advised. The combination of fine ash and gas with dry, hot or windy weather may also require further precautions to be undertaken, such as partial or full evacuation. In addition to the health impacts of fine ash exposure, agriculture is likely to be adversely affected by fine ash and acid rain, especially in the growing seasons of spring and early summer.
The largest considered sub-Plinian eruption is expected to cause significant disruption and hazards but to be relatively short-lived. The shift in wind directions towards the east with increasing altitude means that, in particular, the Port is subject to high hazard (>60\% probability of loads exceeding $10 \mathrm{~kg} / \mathrm{m}^{2}$ ) and there is a possibility of roof collapse for weaker structures in the east (Thera: $10 \%$ to $15 \%$ probability of loads exceeding $200 \mathrm{~kg} / \mathrm{m}^{2}$ ), but also the south of the island (Akrotiri: $15 \%$ to $20 \%$ probability).

The calculations in this assessment proved useful in highlighting areas that would benefit from further data and/or study in preparation for a future eruption. However, they should be regarded as preliminary and with large uncertainties. One of the key limitations in developing the stochastic models presented here was in deriving reliable estimates of model input parameters given uncertain and few data, and with limited time. The ash and gas hazard assessment presented here should therefore be used as a starting point for a refined assessment, to be undertaken prior to another period of unrest or a future eruption. Potential improvements include further investigating historical eruption accounts and geological data at Santorini and analogous volcanoes to improve model input parameters such as grain size distributions, column height estimates or characterisation of eruption timeseries as a Poisson point process. A more accurate description of the source plume dynamics should also be obtained, mostly in terms of vertical mass distribution and wind effects on the plume. Ash thresholds appropriate to an eruption crisis on Santorini should be refined through studies of exposed infrastructure, agriculture and buildings and through discussion with health officials. In particular, assessing short fluctuations in ash and gas hazard will be important from a health perspective. In the event of a future eruption, it will be imperative to make measurements of ash and gas emissions, including time series of plume heights, $\mathrm{SO}_{2}$ fluxes and systematic sampling of the ash, supported by characterisation of its properties, to support future hazard assessments at Santorini and elsewhere.

Assessing the impact of this study on decision-making in relation to disaster planning and disaster risk reduction for the emergency and possible future eruptions on Santorini is difficult. The unrest declined and no eruption ensued. At the height of the unrest there were many concerns and the local authorities consulted several scientists for advice, including two of the authors (RSJS and GV). Many of the results reported in this paper were generated in very short time frames to support this advice. For example Fig. 2 was generated in a single day to inform a meeting with local authorities on Santorini. Research is tangibly and necessarily different in an emergency situation to a classical research project. For example the ash 
modelling work in the UK and Italy were largely independent. We consider that it is a strength that the modelling results are similar and, most importantly, that they came up with the same implications for emergency management. The implications of the assessment were taken seriously and understood by the local authorities at the time but we did not follow up whether these have been subsequently embedded into local civil protection plans. The results were also delivered to the Greek National Committee and were acknowledged, but again we do not know whether subsequent actions were taken. Publication of this emergency research in the peer-reviewed literature will help ensure that the findings are readily available for the next emergency on Santorini and are not lost or made inaccessible, as has sometimes happened in the past in other emergencies in other countries.

\section{Competing interests}

The authors declare that they have no competing interests.

\section{Authors' contributions}

Ash modelling has been carried out by TKH, SB, AN and SFJ and gas modelling by JCP and TS. RSJS developed the eruption scenarios in collaboration with GV. SFJ and SB combined the studies and carried out model comparisons. RSJS and GV provided expertise to the local authorities on Santorini during the emergency. All authors have read and approved the final manuscript.

\section{Acknowledgments}

We thank David Pyle (University of Oxford) for reviewing the choice of eruption scenarios, Sebastian Watt (then Southampton University) for providing detailed information and discussion on the eruption history and Sandy Drimoni (University of Athens) for translating historical documents and providing information on qualitative eruption descriptions. We thank Peter Baxter (University of Cambridge) for discussions and contributions surrounding the health aspects of this study. We also wish to thank two anonymous reviewers for their detailed and insightful comments. We are very grateful for the collaboration with the National Committee of Greece on Santorini who invited us to carry out the ash and gas hazard assessments described here. Finally, we would like to acknowledge the following sources of funding support that made this assessment possible: an AXA research fellowship (SFJ), the STREVA project (NERC/ESRC consortium NE/J019984/1) (JCP, TKH and RSJS), the VOLDIES project (ERC contract 228064) (SFJ, TKH and RSJS), the ESF MEMOVOLC network (AN) and a NERC Environmental Risks to Infrastructure Innovation Programme grant (NE/M008878/1) (SFJ, JCP). This work was also supported by the Global Volcano Model (www.globalvolcanomodel.org) through a NERC International innovations project.

\section{Author details \\ 'Department of Earth Sciences, University of Bristol, Bristol BS8 1RJ, UK. ${ }^{2}$ Istituto Nazionale di Geofisica e Vulcanologia (INGV), Sezione di Pisa, Pisa, Italy. ${ }^{3}$ Icelandic Meteorological Office, Reykjavík, Iceland. ${ }^{4}$ nnstitute of Geology and Mineral Exploration (IGME), Athens, Greece.}

Received: 30 May 2014 Accepted: 5 May 2015

Published online: 27 May 2015

\section{References}

Aspinall WP, Woo G (2014) Santorini unrest 2011-2012: an immediate Bayesian belief network analysis of eruption scenario probabilities for urgent decision support under uncertainty. J Applied Volcanology 3:12

Barsotti, S, Neri, A (2008) The VOL-CALPUFF model for atmospheric ash dispersal: 2. Application to the weak Mount Etna plume of July 2001. J Geophys Res-Sol Ea, 113(B3)
Barsotti S, Neri A, Scire JS (2008) The VOL-CALPUFF model for atmospheric ash dispersal: I. Approach and physical formulation. J Geophys Res 113(B03208):85

Barsotti S, Andronico D, Neri A, Del Carlo P, Baxter PJ, Aspinall WP, Hincks T (2010) Quantitative assessment of volcanic ash hazards for health and infrastructure at Mt Etna (Italy) by numerical simulation. J Volcanol Geotherm Res 192(1-2):85-96

Blong RJ (1984) Volcanic hazards: a sourcebook on the effects of eruptions. Academic, Australia, Sydney, p 424

Bonadonna C, Connor CB, Houghton BF, Connor L, Byrne M, Laing A, Hincks TK (2005) Probabilistic modeling of tephra dispersal: Hazard assessment of a multiphase rhyolitic eruption at Tarawera, New Zealand. J Geophys Res 110(B03203):1-21

Cimorelli AJ, Perry SG, Venkatram A, Weil JC, Paine RJ, Wilson RB, Lee RF, Peters WD, Brode RW (2005) AERMOD: A Dispersion Model for Industrial Source Applications. Part I: General Model Formulation and Boundary Layer Characterization. J Appl Meteorol 44(5):682-693

Dakoronias (1879) De l'influence des emanations volcaniques sur les etres organizes, particulierment etudiée a Santorin pendant l'eruption de 1866. Adrien Delahaye, Paris

Dekigalla J (1881) Diary about the 1866 volcano eruption at the Kameni islands

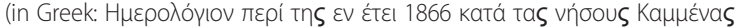

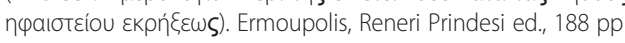

Dominey-Howes D, Minos-Minopoulos D (2004) Perceptions of hazard and risk on Santorini. J Volcanol Geotherm Res 137(4):285-310

Druitt TH, Edwards L, Mellors RM, Pyle DM, Sparks RSJ, Lanphere M, Davies M, Barriero B (1999) Santorini Volcano. Geological Society Memoir No. 19, London, p 176

Fouqué F (1879) Santorin et ses éruptions. G. Macon, Paris, 440 pp

Friedrich WL, Kromer B, Friedrich M, Heinemeier J, Pfeiffer T, Talamo S (2006) Santorini eruption radiocarbon dated to 1627-1600 B.C. Science 312(5773):548

Fytikas M, Kolios N, Vougioukalakis GE (1990) Post-Minoan activity of the Santorini volcano: Volcanic hazard and risk, forecasting possibilities. In: Hardy DA, Keller J, Galanopoulos VP, Flemming NC, Druitt TH (eds) Thera and the Aegean world III. The Thera Foundation, London, pp 183-198

Georgalas GC, Papastamatiou J (1953) L'eruption du volcano de Santorini en 1939-1941; I'eruption du Dome Fouque. Bulletin Volcanogique 13:1-38

Gerlach TM, McGee KA, Doukas MP, Gerlach TM, McGee KA, Doukas MP (2008) Emission rates of $\mathrm{CO}_{2}, \mathrm{SO}_{2}$, and $\mathrm{H}_{2} \mathrm{~S}$, scrubbing, and pre-eruption excess volatiles at Mount St. Helens, 2004-2005, vol 1750, US Geological Survey professional paper. US Geological Survey, Washington DC, pp 543-571

Hellenic Statistical Authority (2011) Census 2011, Accessed 12/07/2013. www.statistics.gr

Hirabayashi Jl, Ohba T, Nogami K, Yoshida M (1995) Discharge rate of $\mathrm{SO}_{2}$ from Unzen volcano, Kyushu, Japan. Geophys Res Lett 22(13):1709-1712

Horwell CJ, Baxter PJ (2006) The respiratory health hazards of volcanic ash: a review for volcanic risk mitigation. Bull Volcanol 69:1-24

ICAO (2010) International Civil Aviation Organization EUR DOC 019 - Volcanic ash contingency plan EUR and NAT regions (2nd Edition), Issued by the EUR/NAT Office of ICAO under the authority of the EANPG and the NAT SPG

Jenkins SF, Spence RJS, Fonseca JFBD, Solidum RU, Wilson TM (2014) Volcanic risk assessment: Quantifying physical vulnerability in the built environment. J Volcanol Geotherm Res 276:105-120

Johns, A., 2010. Modelling gas dispersion from Masaya volcano, Nicaragua, using the industrial source model, AERMOD. MRes Science of Natural Hazards thesis. University of Bristol.

Kténas K (1926) L'eruption du Volcan de Santorini en 1925: Notes Preliminaires. In: Records of Athens Academy, Athens, Part I., pp 75-83

Macedonio G, Costa A (2012) Rain effect on the load of ash deposits. Natural Hazards and Earth FSystems Science, Brief communication 12:1229-1233

Mastin LG, Guffanti M, Servranckx R, Webley PW, Barsotti S, Dean KG, Durant AK, Ewert JW, Neri A, Rose WI, Schneider DJ, Siebert L, Stunder BJ, Swanson G, Tupper A, Volentik A, Waythomas CF (2009) A multidisciplinary effort to assign realistic source parameters to models of volcanic ash-cloud transport and dispersion during eruptions. J Volcanol Geotherm Res 186(1-2):10-21

McGee KA, Doukas MP, McGimsey RG, Neal CA, Wessels RL (2010) Emission of $\mathrm{SO}_{2}, \mathrm{CO}_{2}$, and $\mathrm{H}_{2} \mathrm{~S}$ from Augustine Volcano, Alaska, 2002-2008. In: Power JA, Coombs ML, Freymueller JT (eds) The 2006 eruption of Augustine Volcano, US Geological Survey Professional Paper, 1769. US Geological Survey, Washington DC

Newman AV, Stiros S, Feng L, Psimoulis P, Moschas F, Saltogianni V, Jiang Y, Papazachos C, Panagiotopoulos D, Karagianni E, Vamvakaris D (2012) Recent geodetic unrest at Santorini Caldera, Greece. Geophys Res Lett 39(6):L06309 
Parks MM, Biggs S, England P, Mather TA, Nomikou P, Palamartchouk K, Papanikolaou X, Paradissis D, Parsons B, Pyle DM, Raptakis C, Zacharis V (2012) Evolution of Santorini Volcano dominated by episodic and rapid fluxes of melt from depth. Nat Geosci 5:749-754

Parks MM, Caliro S, Chiodini G, Pyle DM, Mather TA, Berlo K, Edmonds M, Biggs J, Nomikou P, Raptakis C (2013) Distinguishing contributions to diffuse $\mathrm{CO}_{2}$ emissions in volcanic areas from magmatic degassing and thermal decarbonation using soil gas ${ }^{222} \mathrm{Rn}-\delta^{13} \mathrm{C}$ systematics: application to Santorini volcano, Greece. Earth Planet Sci Lett 377-378:180-190

Pyle, D.M., 2000. Sizes of volcanic eruptions. In: H. Sigurdsson, B. Houghton, H. Rymer, J. Stix, S. McNutt (Editors), Encyclopedia of Volcanology. Academic Press, pp. $263-269$

Pyle DM, Elliot JR (2006) Quantitative morphology, recent evolution, and future activity of the Kameni islands volcano, Santorini. Geosphere 2:253-258

Reck H (1936) Santorin. Der Werdegang eines Inselvulkans und sein Ausbach, 1925-1928. Dietrich Reimer/Andrews und Steiner, Berlin, volume 2 of 3

Schmid JFJ (1874) Santorin 1866 bis 1872. Vesuv. Bajae Stromboli, Aetna 1870. Carl Scholtze, Liepzig, p 235

Scire JS, Insley EM, Yamartino RJ (1990) Report. Concord, MA, USA, Sigma Research Corp., Model formulation and user's guide for the CALMET meteorological model

Shinohara H (2008) Excess degassing from volcanoes and its role on eruptive and intrusive activity. Reviews of Geophysics, 46(4)

Smithsonian Institution (2013) Volcanoes of the world: an illustrated catalog of holocene volcanoes and their eruptions. Smithsonian Institution, Global Volcanism Program digital information series, GVP-4. (http://www.volcano.si.edu)

Sparks RSJ, Wilson L (1982) Explosive volcanic eruptions V: Observations of plume dynamics during the 1979 Soufriere eruption, St Vincent. Geophys J Roy Astron Soc 69(55):1-570

Sparks RSJ, Bursik MI, Carey SN, Gilbert JS, Glaze L, Sigurdsson H, Woods AW (1997) Volcanic plumes. John Wiley and sons

Sparks RSJ, Biggs J, Neuberg JW (2012) Monitoring Volcanoes. Science 335(6074):1310-1311

Spence R, Kelman I, Baxter P, Zuccaro G, Petrazzuoli S (2005) Residential building and occupant vulnerability to tephra fall. Natural Hazards and Earth Systems Science 5:477-494

Spinetti C, Barsotti S, Neri A, Buongiorno MF, Doumaz F, Nannipieri L (2013) Investigation of the complex dynamics and structure of the 2010 Eyjafjallajokull volcanic ash cloud using multispectral images and numerical simulations. J Geophys Res-Atmos 118(10):4729-4747

Stiros SC, Psimoulis P, Vougioukalakis G, Fytikas M (2010) Geodetic evidence and modeling of a slow, small-scale inflation episode in the Thera (Santorini) volcano caldera, Aegean Sea. Tectonophysics 494(3-4):180-190

Suzuki T (1983) A theoretical model for dispersion of tephra. In: Shimozuru D, Yokohama I (eds) Arc volcanism: physics and tectonics. Terra Scientific Publishing, Tokyo, pp 95-113

Thorsteinsson T, Jóhannsson T, Stohl A, Kristiansen NI (2012) High levels of particulate matter in Iceland due to direct ash emissions by the Eyjafjallajökull eruption and resuspension of deposited ash. J Geophysical Research 117(B00C05)

Vougioukalakis GE, Fytikas M (2005) Volcanic hazards in the Aegean area, relative risk evaluation and monitoring state of the active volcanic centers. In: Fytikas M, Vougioukalakis GE (eds) The South Aegean Volcanic Arc. Present Knowledge and Future Perspectives, vol 7. Elsevier Series Developments in Volcanology, Amsterdam, pp 161-184

Watt SFL, Mather TA, Pyle DM (2007) Vulcanian explosion cycles: Patterns and predictability. Geology 35(9):839-842

Wilson TM, Stewart C, Sword-Daniels V, Leonard GS, Johnston DM, Cole JW, Wardman J, Wilson G, Barnard ST (2012) Volcanic ash impacts on critical infrastructure. Physics and Chemistry of the Earth, Parts A/B/C 45-46:5-23

Woodhouse MJ, Hogg AJ, Phillips JC, Sparks RSJ (2013) Interaction between volcanic plumes and wind during the 2010 Eyjafjallajökull eruption, Iceland. J Geophysical Research: Solid Earth 118(1):92-109, www.plumerise.bris.ac.uk

Zehner C (2010) Monitoring Volcanic Ash from Space. Proceedings of the ESA-EUMETSAT workshop on the 14 April to 23 May 2010 eruption at the Eyjafjöll volcano, South Iceland. ESA-Publication STM-280, Frascati, Italy. doi:10.5270/atmch-10-0

\section{Submit your manuscript to a SpringerOpen ${ }^{\odot}$ journal and benefit from:}

- Convenient online submission

Rigorous peer review

- Immediate publication on acceptance

- Open access: articles freely available online

- High visibility within the field

- Retaining the copyright to your article

Submit your next manuscript at $>$ springeropen.com 